\title{
Effects of Lake Trout Refuges on Lake Whitefish and Cisco in the Apostle Islands Region of Lake Superior
}

Chiara M. Zuccarino-Crowe ${ }^{*, a, 1}$, William W. Taylor ${ }^{\mathrm{a}}$, Michael J. Hansen ${ }^{\mathrm{b}, 2}$, Michael J. Seider ${ }^{\mathrm{c}, 3}$, and Charles C. Krueger ${ }^{\mathrm{d}}$

${ }^{a}$ Center for Systems Integration and Sustainability, Department of Fisheries and Wildlife, Michigan State University, 1405 S. Harrison Rd., Suite 115 Manly Miles Bldg., East Lansing, Michigan 48823, USA; Email: c.zuccarino.crowe@gmail.com Phone: 858-366-2870

${ }^{\mathbf{b}}$ College of Natural Resources, University of Wisconsin - Stevens Point, 800 Reserve Street, Stevens Point, Wisconsin 54481, USA; Email: michaelhansen@usgs.gov

${ }^{\mathbf{c}}$ Wisconsin Department of Natural Resources, 141 South Third Street, Bayfield, Wisconsin 54814, USA; Email: mike_seider@fws.gov

${ }^{\mathrm{d}}$ Center for Systems Integration and Sustainability, Department of Fisheries and Wildlife, Michigan State University, 1405 S. Harrison Rd., Suite 115 Manly Miles Bldg., East Lansing, Michigan 48823, USA; Email: Kruege62@anr.msu.edu

*Corresponding author: Chiara M. Zuccarino-Crowe (email: c.zuccarino.crowe@ gmail.com; Phone: 858-366-2870) 
Abstract: Lake trout refuges in the Apostle Islands region of Lake Superior are analogous to the concept of marine protected areas. These refuges, established specifically for lake trout (Salvelinus namaycush) and closed to most forms of recreational and commercial fishing, were implicated as one of several management actions leading to successful rehabilitation of Lake Superior lake trout. To investigate the potential significance of Gull Island Shoal and Devils Island Shoal refuges for populations of not only lake trout but also other fish species, relative abundances of lake trout, lake whitefish (Coregonus clupeaformis), and cisco (Coregonus artedi) were compared between areas sampled inside versus outside of refuge boundaries. During 1982-2010, lake trout relative abundance was higher and increased faster inside the refuges, where lake trout fishing was prohibited, than outside the refuges. Over the same period, lake whitefish relative abundance increased faster inside than outside the refuges. Both evaluations provided clear evidence that refuges protected these species. In contrast, trends in relative abundance of cisco, a prey item of lake trout, did not differ significantly between areas inside and outside the refuges. This result did not suggest indirect or cascading refuge effects due to changes in predator levels. Overall, this study highlights the potential of species-specific refuges to benefit other fish species beyond those that were the refuges' original target. Improved understanding of refuge effects on multiple species of Great Lakes fishes can be valuable for developing rationales for refuge establishment and predicting associated fish community-level effects.

\section{Keywords:}

MPA; reserve; Great Lakes; native fish; harvest regulation; fisheries management 


\section{Introduction}

Marine protected areas (MPAs) are a tool in conservation of biodiversity and management of marine ecosystems (Agardy et al., 2003; Halpern and Warner, 2002; NRC, 2001). From a fishery perspective, prohibiting harvest or disturbance of fish habitat in designated zones within MPAs (also known as marine reserves) can allow overfished stocks to recover and benefit yield in areas adjacent to reserves (Gell and Roberts, 2003; Halpern et al., 2010; Roberts et al., 2005; Russ and Alcala, 1996; Vandeperre et al., 2010). The same management approach can be applied in freshwater systems, but the extent of implementation and published evaluation of aquatic protected areas (APAs) is not as common as MPAs in marine environments (Abell et al., 2007; Hedges et al., 2010; Suski and Cooke, 2007). In the Laurentian Great Lakes, APAs have been implemented as management tools; and their use over several decades provides an opportunity to evaluate their long-term effects on freshwater species and local fisheries (Hedges et al., 2011).

Great Lakes APAs were established for various cultural and ecological purposes, ranging from protection of Great Lakes maritime heritage sites, such as shipwrecks, to restoration of fish populations (Hedges et al., 2010). Six APAs in lakes Superior, Huron, and Michigan are specifically closed to recreational and commercial harvest of lake trout (Salvelinus namaycush) to aid in recovery of local populations (MDNR, 2011; Stanley et al., 1987; WDNR, 2011). Stocks of this native piscivore collapsed across the upper Great Lakes by 1950 because of overexploitation, sea lamprey (Petromyzon marinus) predation, and possibly by habitat degradation of traditional near-shore spawning areas (Hansen, 1999; Krueger and Ebener, 2004; Krueger et al., 1995; Muir et al., 2012). Provincial, state and tribal fishery management agencies collaborated with federal governments and the Great Lakes Fishery Commission to rehabilitate lake trout populations through fishery regulation, stocking, and sea lamprey control. The use of APAs in this process included establishment of areal fishery closures (referred to as refuges in this regulatory context) that were closed to year-round lake trout harvest and were sites of intensive stocking. These lake trout refuges were designed to encompass areas known to include lake trout spawning reefs, because protection of spawning populations might increase recruitment and wild fish production (Hansen et al., 1995; Holey et al., 1995; Schram et al., 1995; Stanley et al., 1987; Swanson and Swedberg, 1980). While refuges in Lake Michigan and Lake Huron allow harvest of other species (MDNR, 2011), fishery restrictions in Lake Superior 
refuges generally extended to all fish species, except in designated areas for limited fisheries. Extensive long-term monitoring within and adjacent to these refuges has been used to assess progress toward lake trout rehabilitation goals (e.g., Schram et al., 1995). Previous analyses in Lake Michigan (e.g., Madenjian and DeSorcie, 1999) and Lake Huron (e.g., Madenjian et al., 2008) provided mixed conclusions regarding effectiveness of refuges in improving lake trout stock abundance, survival, growth, spawning success, and natural reproduction. In contrast, in Lake Superior, lake trout rehabilitation has been consistently associated with the role of refuges and evaluated based on establishment of self-sustaining populations (e.g., Bronte et al., 1995a; Hansen et al., 1995; Linton et al., 2007; Schram et al., 1995).

Within one of the Lake Superior refuges, Gull Island Shoal Refuge (Figure 1), increased recruitment and lake trout abundance followed in the years immediately after refuge establishment (Swanson and Swedberg, 1980). This initial success was possibly further enhanced by low fishing effort in Michigan waters immediately east of the Gull Island Shoal refuge during the 1970s and early 1980s, thereby increasing the total area with low fishing mortality (Schram et al., 1995). However, increased survival initially observed after refuge implementation continued into the 1990s (Pollock et al., 2007) despite late 1980s increases in commercial fishing pressure in these adjacent waters. Subsequent analyses further highlighted the value of the refuge's protection and role in the ongoing recovery of lake trout in the region (e.g., Johnson et al., 2015).

The population's recovery was supported by observations of density dependent effects on growth, recruitment, and age at first maturity. By 1990, a truncated lake trout age structure with few old fish in non-protected inshore areas of the Apostle Islands contrasted with a much wider age distribution in offshore refuge-protected areas (Hansen et al., 1996). Faster growth of lake trout subject to exploitation in non-protected inshore areas than in the Gull Island Shoal refuge suggested density-dependent growth, possibly due to changes in prey fish abundance (Hansen et al., 1996). This trend was accompanied by declines in recruitment from 1988 through 1995 , potentially driven by intra-specific competition and limited food availability, which indicated a population whose recovery was approaching carrying capacity (Corradin et al., 2008). In later years, wild fish matured at a similar length, but older age, inside compared to outside the refuge during 2001-2010 (Johnson et al. 2015). These observations were all consistent with densitydependent feedback associated with dynamics reported in marine reserves (e.g., Sánchez Lizaso 
et al., 2000), thereby supporting a conclusion that the refuge had an effect on local population dynamics of lake trout. Recent assessments further demonstrated that the Gull Island Refuge afforded enough protection to sustain the lake trout population across a wide range of plausible fishing mortality rates, and that removal of the refuge would risk population collapse at much lower fishing mortality (Akins et al., 2015).

Evaluation of Devils Island Shoal refuge has also highlighted the refuge's role in past efforts to re-establish spawning lake trout populations at the site (Bronte et al., 2002). Increased wild lake trout abundance observed within this refuge during 1985-1997 was linked to ageclasses arising from lake trout embryos planted in turf incubators on Devils Island Shoal (Bronte et al., 2002). This success was partially attributed to the protection from harvest provided by the refuge in addition to embryo stocking, thereby aiding in survival of recruits to spawning age (Bronte et al., 2002).

The two refuges' collective contribution to lake trout population recovery in the Apostle Islands region of Lake Superior raises the question of how refuges might affect other fish species of management priority in the region. Previous studies in marine areas have shown evidence that fishing closures can have indirect, and even trophic cascading effects (Babcock et al., 2010; Pinnegar et al., 2000; Salomon et al., 2002), as demonstrated through population shifts in invertebrates linked to protected fish species at higher trophic levels. Although less prevalent, isolated evaluations of no-take marine reserves have also suggested negative secondary effects on prey species that underwent increased predation by protected fishes (Graham et al., 2003). The focus on broad fish assemblages and multi-species models for MPAs (Baskett et al., 2007) highlights the need for inclusion of conspecific species in MPA or APA evaluations.

Lake Superior fishery managers have long worked towards achieving carefully developed fish community objectives that involve species in addition to lake trout (Horns et al., 2003). These management objectives allow for sustainable harvest of conspecific species, as well as maintaining a forage base to support other species of importance for commercial and recreational fisheries. Two key species of focus in the objectives are the lake whitefish (Coregonus clupeaformis) and cisco (C. artedi). In addition to dominating Lake Superior's commercial fishery since the late 1980s (Bronte et al., 2003), lake whitefish also support the largest contemporary commercial fishery in the Apostle Islands (Seider and Schram, 2011) and across the Great Lakes (Ebener et al., 2008a). Lake trout restoration management indirectly affected 
lake whitefish management because large-mesh gill-net fishing effort in the lake whitefish fishery was limited to reduce incidental lake trout bycatch (Ebener et al., 2008a; Hansen et al., 1995). In addition, cisco stocks (a native species) interacted with rainbow smelt (a non-native species) as lake trout prey, while also supporting an important commercial fishery in Lake Superior. The cisco fishery largely targeted spawning aggregations (Dryer and Beil, 1964; Lawrie and Rahrer, 1973; Selgeby, 1982), and its economic importance in Lake Superior was even more prominent after the collapse of the commercial lake trout fishery in Wisconsin (Selgeby, 1982). Originally supporting the foremost fishery in the Great Lakes from the early 1900s onwards (Dryer and Beil, 1964), cisco stocks collapsed by the early 1960s in the Apostle Islands region near Gull Island Shoal, possibly due to excessive exploitation (Selgeby, 1982). However, others asserted that the decline of cisco and subsequent challenges to rebuilding their populations was linked to lake trout food web dynamics (Gorman et al., 2010; Stockwell et al., 2009) coupled with predation on larval cisco by rainbow smelt (Myers et al., 2009). These ecological ties and management considerations provide a rationale for further inquiry into the refuges' effects on non-target species.

Our research evaluated effects of the Gull Island Shoal and Devils Island Shoal refuges, not only on lake trout, but also on lake whitefish and cisco. Our rationale for focusing on the latter two species was based on their commercial and ecological relevance. Similar to lake trout, lake whitefish and cisco are native species that historically were managed and monitored concurrently as components of the Great Lakes fishery and ecosystem (Bronte et al., 2003; Ebener et al., 2008a; Hansen, 1999; Stockwell et al., 2009). Our study objectives were to determine if: 1) relative lake trout abundance differed inside and outside of refuges, to corroborate other evaluations of the effect of the Gull Island Refuge on lake trout recovery in the Apostle Islands region (e.g., Johnson et al. 2015); and 2) refuges directly or indirectly affected relative abundance of two non-target species, the lake whitefish and cisco in this area. Evaluation of lake trout data was used to confirm our analytical approach for evaluating refuge effects on lake whitefish and cisco. We reasoned that if our results confirmed results of previous analyses - that refuges contributed positively to lake trout restoration in the region - it would validate our approach to evaluate effects of these refuges on lake whitefish and cisco. We hypothesized that lake whitefish would benefit from protection from fishing mortality, whereas 
cisco would be subjected to greater predation by the high-density lake trout population within the refuge.

\section{Methods}

Study Site

Fishery-independent survey data were collected from waters of the Apostle Islands region of Lake Superior, which is located along the southwestern coast within waters under the jurisdiction of the state of Wisconsin (Figure 1). The archipelago has 22 islands and is contained within a single lake trout management unit, WI-2 (Smith et al., 1961). The area is characterized by numerous underwater rocky reefs and shoals, complex shorelines, and a wide range of depths that provide an abundance of fish habitat (Coberly and Horrall, 1980). Most waters in this area are less than $80 \mathrm{~m}$ deep, although a trench along the eastern portion reaches a depth of $140 \mathrm{~m}$.

The two refuges were created to aid recovery of lake trout populations in Lake Superior (Hansen et al., 1995; Stanley et al., 1987; Swanson and Swedberg, 1980). Gull Island Shoal Refuge and Devils Island Shoal Refuge were designated to encompass areas historically important for lake trout spawning (Coberly and Horrall, 1980) - areas that had also been heavily fished prior to establishing a refuge around the Gull Island Shoal (Schram et al., 1995; Swanson and Swedberg, 1980). This first refuge was established in 1976 to protect an important remnant spawning stock of lake trout (Hansen et al., 1995; Schram et al., 1995; Stanley et al., 1987; Swanson and Swedberg, 1980). The Devils Island Shoal Refuge was established in 1981 to complement fingerling and fertilized egg-stocking efforts (Swanson, 1982) toward reestablishing a naturally reproducing stock at this historic spawning location (Bronte et al., 2002; Coberly and Horrall, 1980; Hansen et al., 1995; Stanley et al., 1987). The maximum area of the Gull Island Shoal Refuge is $447 \mathrm{~km}^{2}$, and the area of the Devils Island Shoal Refuge (not including open fishing zones during certain seasons) is $478 \mathrm{~km}^{2}$. Together, the closed fishing areas of the two refuges cover $21 \%$ of the total area of the WI-2 management unit.

When established, the refuges' primary purpose was to prohibit commercial and recreational fishing for all species. However, since their establishment, some areas have been periodically exposed to low, sporadic levels of fishing for species other than lake trout, such as deep-water chubs (Coregonus species) in waters deeper than $64 \mathrm{~m}$ (Figure 2). We have assumed 
that effects of these other fisheries were negligible on trends in relative abundance of fishes sampled during assessment surveys.

\section{Data Collection}

Lake trout, lake whitefish, and cisco were collected during a standardized graded-mesh gill-net survey conducted during the summer months from 1970-2010 (Johnson et al., 2015). Graded mesh gill nets (of $\sim 1$ kilometer in length) were deployed for 24 hours (i.e., 1-km net night) at fixed stations with an average depth of 34 meters (range 8-128 meters). Due to the low number of stations during the 1970s located within the areas that would become refuges, we limited our analyses to years after 1981, the time after which both refuges had been established. After 1980, the survey was only conducted in even-numbered years (except in 1996), so the subset of the data used for statistical analyses included data collected in 14 even-numbered years from 1982 through 2010 at 61 stations. Of these stations, 14 were located inside the refuges (eight in Devils Island Shoal Refuge and six in Gull Island Shoal Refuge) and 47 stations were located outside the refuges (see Figure 2). Of the 61 stations, 33 were not sampled in some years, but contributed important data to quantify trends, while the remaining 38 were sampled in each of the 14 years (Johnson et al., 2015).

\section{Analytical Approach}

Annual mean catch per unit of effort (CPUE, fish/ 1-km net night) was compared between stations inside and outside of refuges during 1982-2010 using a general linear model. Annual mean CPUE was calculated across the two refuges to limit the potential for locationspecific bias associated with a single protected area (Willis et al., 2003).

Mean annual log-transformed catch of each species sampled at stations inside and outside refuges were plotted against years from 1982 through 2010. Given past analyses that showed wild lake trout were more successful than stocked lake trout for driving recruitment in the area (Corradin et al., 2008; Hansen et al., 1995; Krueger et al., 1986), trends in CPUE of wild and stocked lake trout (all stocked fish are fin-clipped and therefore identifiable) were analyzed separately.

Significance of patterns visualized in the data were tested using multiple linear regression of CPUE data using an explanatory model developed to account for refuge effects over time. 
The model was modified from the exponential population growth model (Quinn and Deriso, 1999) (equation 1):

$$
N_{t}=N_{0} * e^{\left(r^{*} t\right)}
$$

Where $N_{t}$ is the population at time $t, N_{O}$ is initial population size, and $r$ is the instantaneous rate of population growth. The model was expanded to include a variable for refuge status ("inside" versus "outside") and its effects over time (equation 2):

$$
N_{t}=N_{0} * e^{\wedge}\left[\left(r^{*} t\right)+\left(b_{2} * R\right)+\left(b_{3} * R * t\right)+\varepsilon\right]
$$

Relative abundance $\left(N_{t}\right)$ is equivalent to catch-per-unit-effort (CPUE) as the response variable, $R$ represents an indicator variable for refuge status, $t$ represents the continuous variable of time in years, and $\varepsilon$ represents the error associated with the model. Independent variables were treated as fixed effects.

The exponential growth model (equation 2) was log-transformed to linearize the model into a general linear model (equation 3):

$$
\log _{e}(C P U E)=\beta_{0}+\left(\beta_{1} * t\right)+\left(\beta_{2} * R\right)+\left(\beta_{3} * R * t\right)+\varepsilon
$$

Where $\beta_{0}$ is the logarithm of the initial population size $\left(N_{0}\right), \beta_{1}$ is the instantaneous population growth rate, $\beta_{2}$ is the magnitude of the refuge main effect, and $\beta_{3}$ is the strength of the interaction term. To accommodate log-transformation of zero catches, 0.5 was added to each catch before transformation (Yamamura, 1999). A term for the interaction of time and refuge status in the model was included to test homogeneity of slopes in CPUE over time between refuge and nonrefuge stations. The general linear model was estimated with the "lm" function in the "stats" package for R (R Development Core Team 2011). To visualize model results, we plotted predicted values over the calculated annual log-transformed means of relative abundance. This analysis was repeated for each species' catch data, and for wild and stocked lake trout.

Residuals were tested for normality, equal variance, and independence of errors. To determine if errors were independent, we visually inspected plots of model residuals against time and plots of autocorrelation estimates against time lags using the "acf" function in the R "stats" package (R Development Core Team 2011). A Durbin-Watson test for autocorrelation was performed with the "dwt" function in the "car" package (Fox and Weisberg, 2011) for R (R Development Core Team, 2011). 


\section{Results}

Relative abundance of wild lake trout was lower than that of stocked lake trout inside and outside of refuges in the early 1980s, but wild lake trout quickly increased inside refuges and predominated from 1986 onward (Figure 3). After 1996 (stocking ceased in 1994), stocked lake trout declined, and relative abundance fell below wild lake trout both inside and outside of refuges (Figure 3). Relative abundance of wild lake trout CPUE $\left(F_{3,689}=89.3 ; P=<0.01\right)$ was better explained by this model $\left(R^{2}=28 \%\right)$ than a combined analysis that included hatchery origin-fish (Table $1, F_{3,689}=36 ; P<0.01, R^{2}=13 \%$ ). Wild fish increased inside and outside of refuges (Figure 4a), but at a faster rate inside than outside these refuges (significant interaction effect in the model, $\mathrm{P}<0.01$, Table 1). In contrast, stocked lake trout decreased overall (Figure $4 \mathrm{~b}$ ), and trends in relative abundance of stocked fish did not differ between inside and outside refuges areas (non-significant interaction; Table 1). However, the main effects of year and refuge status were significant descriptors of stocked lake trout CPUE (Table 1). By supporting previous analyses' conclusion that refuges contributed positively to wild lake trout restoration in the area, these complimentary results confirmed the validity of our analytical approach for evaluating effects of the refuges on other species.

Graded-mesh gill net surveys showed increases in annual mean lake whitefish CPUE after both refuges were established (Figure 5). From 1982 through 2010, mean log-transformed lake whitefish CPUE increased faster inside than outside of these refuges, but was consistently lower inside than outside of the refuges (Figure 6; significant refuge and interaction effects, $\mathrm{P}<0.01$, Table 1). The lake whitefish model explained $33 \%$ of the variation in log-transformed $\operatorname{CPUE}\left(F_{3,689}=113.2 ; P<0.01\right)$. Additionally, trends in lake whitefish CPUE converged over time inside and outside of refuges (Figure 6), although the rate of increase in annual mean logtransformed CPUE decreased through time inside and outside of these refuges, especially after 2000 (Figures 5-6).

Annual mean cisco CPUE collected during graded-mesh surveys increased after both refuges were implemented (Figure 7). However, the cisco model explained only $3 \%$ of the variation in log-transformed $\operatorname{CPUE}\left(F_{3,689}=7.99 ; P<0.01\right)$ and none of the model terms significantly described the variation reported (Table 1). Log-transformed CPUE was greater outside $($ mean $=3.035 ;$ standard error $=0.081)$ than inside $($ mean $=2.218$; standard error $=$ $0.154)$ of these refuges when year was not included in the model $\left(F_{2,691}=805.5 ; P<0.01\right)$. 
Model residuals (for this and for all previous models mentioned above) satisfied assumptions of normality, equal variance, and independence.

\section{Discussion}

Our results showed that refuges directly enhanced relative abundances of lake trout (the target species) and lake whitefish (a non-target species of the refuges), but not of cisco, in the Apostle Islands region of Lake Superior. Whereas the effect of refuges on lake trout has been reported before (e.g., Johnson et al., 2015, Swanson and Swedberg, 1980), the analyses presented here are the first to show a refuge effect on lake whitefish in the Great Lakes as demonstrated by the relatively faster increase in abundances of this species within refuges than in surrounding areas where the species is subjected to harvest. Future management decisions should therefore consider the contribution of these refuges for sustaining both lake trout and lake whitefish stocks in the eastern Wisconsin waters of Lake Superior.

The findings of this research corroborate previous studies of direct refuge effects on lake trout rehabilitation in Lake Superior, particularly within the Apostle Islands (Bronte et al., 1995a; Fabrizio et al., 2001; Hansen et al., 1996; Hansen et al., 1995; Johnson et al., 2015; Pollock et al., 2007; Schram et al., 1995; Swanson and Swedberg, 1980). For example, stocked lake trout declined greatly after stocking ceased, whereas wild lake trout increased greatly in response to increased recruitment and reduced fishing mortality (Corradin et al., 2008; Hansen et al., 1995; Krueger et al., 1986). Reductions in the rate of increase in annual mean relative abundance since 2000 suggests that population growth is approaching carrying capacity (Corradin et al., 2008), where density-dependent compensatory processes reduce population growth and simultaneously induce spillover into adjacent areas (Botsford et al., 2009; Sánchez Lizaso et al., 2000). However, density-dependent survival must also be demonstrated within these refuges to confirm that lake trout stocks have been restored (Bronte et al., 1995a; Schram et al., 1995; Wisconsin State-Tribal Technical Committee, 2009), a characteristic that is still uncertain in these refuges at this time. Recent reductions in lake trout growth, altered age at maturity, and decreased mortality were indicative of a population under flux that has not yet reached equilibrium (Johnson et al., 2015). This conclusion serves as a reminder that lake trout CPUE is likely influenced by other variables, beyond just time and refuge status, such as intraspecific competition and species interactions. 
Regardless, the higher and increasing abundance of lake trout inside than outside of refuges is important for contributing to numbers in adjacent areas when spillover of high densities of predators inside reserves serves as a source of fishable biomass in adjacent nonprotected areas (NRC, 2001; Russ and Alcala, 1996; Sánchez Lizaso et al., 2000). Spillover has likely occurred in the Apostle Islands region given the mean home ranges of lake trout (44 km during non-spawning season and $9.5 \mathrm{~km}$ during spawning season, Kapuscinski et al., 2005). Although consideration of the negative impact of species mobility on the extent of reserve effectiveness is prevalent in the literature, especially when the predator is highly mobile and therefore not protected during lengthy travels beyond reserve boundaries (Botsford et al., 2009; Hilborn et al., 2004; Le Quesne and Codling, 2009; Shipp, 2003), reserves can affect relatively mobile species regardless of whether individuals' behavior results in them remaining in the reserve only during spawning seasons or for longer periods of time (Willis et al., 2003). Our results further support others' conclusions that the refuges in the Apostle Islands effectively limited lake trout fishing mortality, regardless of the refuges' areal extent of year-round protection or temporary protection of emigrating fish (Hedges et al., 2010; Pollock et al., 2007). Not only are adult lake trout protected during a vulnerable period (spawning), but after eggs hatch, areas adjacent to the refuge are provided with recruits via dispersal of fry (Bronte et al., 1995b; Pelc et al., 2010). The fisheries implications of these benefits are paralleled in harvest data. The increase in relative abundance of wild lake trout occurred alongside generally steady harvest levels, with declines in commercial harvest (reflective of fishery management decisions) occurring while recreational fishery harvest increased slightly from 1980 through 2001 (Linton et al., 2007). Fishery yields over the next five years (2001-2005) trended upward, and total harvest from fishable parts of the Apostle Islands region remained higher than in other parts of Lake Superior (Sitar et al., 2010).

Our results also indicated that lake whitefish populations increased faster inside than outside of the refuges in the Apostle Islands region of western Lake Superior. While other management actions and environmental conditions also likely contributed to this trend (Ebener, 1997; Ebener et al., 2008a; Seider and Schram, 2011), our results suggested that protection from harvest provided by the refuges contributed to an increased rate of population growth. Unlike lake trout, lake whitefish relative abundance was lower inside than outside of refuges, which may be due to a habitat preference for areas outside refuges and not included within refuges. This 
preference could be reflective of that, except for a couple of productive sites along the southern end of the Devils Island Shoal Refuge, most known historic lake whitefish spawning sites were located near the islands and shoals not located within the boundaries of the refuges (Coberly and Horrall, 1980). Alternatively, contrasting patterns of relative abundance for lake trout and lake whitefish could also indicate an interaction between lake whitefish and lake trout, although lake whitefish have rarely been found in lake trout stomachs (Conner et al., 1993; Ray et al., 2007). Our use of an analytical approach that incorporated both time and refuge status allowed for testing of changes in relative abundance independent of the spatial distribution of lake whitefish habitat, which we assumed did not change during the study period. The reduced rate of increase in annual mean lake whitefish relative abundance inside and outside of refuges in more recent years could also be caused by density-dependence, which led to a declining growth rate of lake whitefish in the Apostle Islands (Bronte et al., 2003; Seider and Schram, 2011). Tagging studies conducted in the Apostle Islands region prior to the mid-1970s demonstrated that lake whitefish remained in the management area (Seider and Schram, 2011), mostly within a radius extending approximately $8 \mathrm{~km}$ away from tagging sites (Dryer, 1964). As lake whitefish populations reach carrying capacity inside refuges, they would likely move to adjacent areas (spillover), where they would be vulnerable to fishery harvest. The increase in commercial harvest of lake whitefish in the Apostle Islands over the last four decades (Seider and Schram, 2011) marked with fluctuating levels of fishing effort (Ebener and Schreiner, 2007), lends support to this theory. The extent of spillover could increase beyond the local management unit if the changes to contemporary movement patterns (wider ranges during non-spawning seasons) recently observed for lake whitefish stocks in northern parts of lakes Michigan and Huron (Ebener et al., 2010) also hold true for Lake Superior stocks.

The management implications of the potentially beneficial refuge effects on lake whitefish are especially relevant given the species' population dynamics, which are highly malleable and strongly affected by variations in density and external forces such as climate (Taylor et al., 1987). Management actions that provide a buffer against the species' inherent recruitment variability, such as protected areas, are beneficial for efficiently maintaining moderate lake whitefish spawning stocks (Taylor et al., 1987). These refuges, intended for protection of lake trout, could therefore benefit lake whitefish populations by providing 
insurance against confounding aspects of lake whitefish population responses to changing climatic conditions.

We expected to find that relative abundance of cisco would decline over time as an indirect refuge effect caused by predation from increasing numbers of lake trout within refuges in the Apostle Islands region of western Lake Superior. This hypothesis was founded on analyses of marine reserves, in which negative effects of reserves on non-target species was attributed to trophic interactions between recovered predatory target species that caused subsequent declines in prey species (Babcock et al., 2010). The overall lower abundance of ciscoes inside refuges initially hints at a trophic interaction linked to greater density of lake trout in those areas. However, we did not detect trends in cisco relative abundance over time that would support the conclusion related to indirect refuge effects. While this result might be because refuges actually did not affect cisco populations, other confounding variables might also have had an effect. One explanation is that the time series we evaluated did not extend long enough to demonstrate refuge-linked trophic interactions. Measureable indirect effects have been shown to lag many years behind direct effects in evaluations of marine reserves, possibly due to broader ecosystem changes or avoidance behavior of prey species (Babcock et al., 2010). In addition, ciscoes are not the only prey item of lake trout in the Apostle Islands, nor are lake trout the only predator of cisco. Oscillating trends in prevalence of prey species (such as rainbow smelt and cisco) in lake trout diets in Lake Superior further exemplifies this complex interaction (Ray et al., 2007). This makes measurement of an indirect refuge effect more difficult unless aggregated data are evaluated at a functional group scale (Pinnegar et al., 2000).

Lastly, high variability of cisco relative abundance may have limited the power of our analysis to detect a trend. Cisco year-class strength is highly erratic, and the species shifts between pelagic and benthic orientation with sex and life history stage, which increases spatial and temporal variability (Stockwell et al., 2009; Stockwell et al., 2006; Yule et al., 2006). Cisco tend to congregate at inshore benthic zones prior to migrating higher in the water column to spawn and thus demonstrate no particular preference for substrate type (Dryer and Beil, 1964; Selgeby, 1982) which affects their catchability in pelagic and benthic sampling gears, and thereby increases variance in assessment fisheries. Further, shifts in habitat used by life stages also affect how cisco populations are targeted by a fishery. For example, gravid females are predominantly pelagic during the spawning season and are targeted by the fishery for roe (egg) 
harvest (Yule et al., 2006). Such fishing practices may further confound trend analysis, given fishing activity in special use zones of Gull Island Shoal refuge where cisco harvest was allowed during a limited portion of the spawning season (Figure 2). Changes in overall levels of fishing effort are unlikely to have affected results in earlier portions of the time series, given the limited variability in effort in the Apostle Islands through 2003 (Ebener et al., 2008b). Subsequent years, however, showed a substantial increase in effort and harvest in the region (Pratt et al., 2016) emphasizing a recognized need from Lake Superior fisheries managers to better understand the potential population effects of the growing contemporary roe fishery (Pratt et al., 2016; Yule et al., 2010).

\section{Management Implications}

Refuges or APAs may benefit resource management beyond direct effects of rebuilding fish stocks within or increasing fishery harvest outside of refuge boundaries. For instance, APAs can serve as a reference area, theoretically only affected by natural mortality, for research and stock assessment in the absence of variability and uncertainty induced by fishing mortality (Stanley et al., 1987). Consequently, refuges can be used as part of a system-wide adaptive ecosystem-based management framework to aid in establishing target reference points or performance indicators for stock management (Babcock and Pikitch, 2004). In addition, reserves may aid in development of alternative controls to evaluate fishery management strategies, in which the ratio of fish density between reserve and non-reserve areas is used instead of the percentage of spawning stock biomass theoretically protected from fishing mortality (Babcock and MacCall, 2011). Given the potential refuge effects observed in this study for lake trout and lake whitefish, two species of importance for fishery management, Great Lakes managers may want to further consider how these refuges can serve purposes beyond population rehabilitation.

Effects of refuges and APAs in the future may change in the face of environmental change or stress, such as degraded habitat caused by hypoxia or sedimentation, which can render areas unsuitable for fish, especially during specific life stages such as spawning. Given temperature changes already observed in the Great Lakes region, in addition to future projections of climate change and associated alterations to local weather patterns and lake thermal structure, the extent of available fish habitat will likely change (Lynch et al., 2010). Protected areas either may not be able to serve an intended purpose, or may be rendered unnecessary if the fish community shifts in ways that require revised fishery management goals, such as the need for an 
increased prey-base to support expanded ranges of valued predatory species, so planning of reserves should account for such changes (Soto, 2001). Dynamically designed reserves may need to be implemented. For example, reserve zoning that allows for shifting conditions has already been mentioned as a potential tactic in terrestrial (Bengtsson et al., 2003; Peters and Darling, 1985) and marine (Soto, 2001) systems, and may need to be considered in the Great Lakes as climate change affects the ecological structure and function of these aquatic systems.

No-take reserves (refuges or APAs where all harvest is prohibited) are not sufficient alone for sustaining fisheries, but rather, are one of many tools used in natural resource management (Agardy et al., 2003; Agardy et al., 2011; Allison et al., 1998; Hedges et al., 2010; Hilborn et al., 2004). In addition, reserves do not exist in a vacuum, but are affected by a whole suite of ecological, social, cultural, economic, and political conditions that affect reserve performance and public acceptance (Pollnac et al., 2010). Restriction of stakeholder activities, especially within commercial, recreational, and subsistence fishing sectors, often creates controversy that complicates fishery management policy decisions. A lack of public consensus on use of no-take fishing zones in fishery management may affect the level of agency attention and support of refuge implementation and assessment. Management complexity takes on added dimensions when no-take reserves are implemented within a matrix of multi-use zoning that can overlap in APAs with other conservation priorities. The lake trout refuges evaluated within this study exist within a broader context of other protected areas (e.g., Apostle Islands National Lakeshore) and resource use by local communities, including indigenous peoples. As a result of this complex landscape, ecological and socio-political considerations should be integrated into management actions (Hughes et al., 2005; Liu et al., 2007). Protected areas such as these exist within a system composed of an interacting web of feedback loops from different sectors, which need to be fully understood when designing and implementing refuges or APAs.

We limited the scope of this evaluation of lake trout refuges in the Apostle Islands region of western Lake Superior, to focus only on lake trout, lake whitefish, and cisco. Other refuge objectives (e.g., conservation of cultural heritage of indigenous peoples) require different forms of discourse and analytical approaches for evaluation. However, within the framework of recreational and commercial fisheries, the explanatory model we used to evaluate trends in relative abundance of select species provided protection from harvest suggested these refuges promoted and sped recovery of not only lake trout, but also lake whitefish populations. Our 
findings support conclusions that relative abundances of these species were enhanced by refuges over the last several decades, and that the refuges may continue to protect more populations of fishes than just lake trout, the original target species.

\section{Acknowledgements}

This research was primarily supported by a National Science Foundation Graduate Research Fellowship under Grant No. DGE-0802267, with additional support from a Janice Lee Fenske Excellence in Fisheries Management Fellowship. The authors would like to thank the biologists and technicians of the Wisconsin Department of Natural Resources, Bayfield field station, including crewmembers of the R/V Hack Noyes, who collected the data used for this research through decades of field surveys. Additional assistance with the conceptual formation of this study was provided by Owen Gorman (USGS), Charles Bronte (USFWS), and Bill Mattes (GLIFWC). We would also like to extend thanks to Jack Liu, Michael Nelson, Dan Hayes, Matt Catalano, Brian Irwin, Dana Infante, Neil Carter, and Abigail Lynch for their technical advice and thoughtful comments during initial drafts of this manuscript. Use of trade, product, or firm names is for descriptive purposes and does not imply endorsement by the U.S. Government. The findings and conclusions in this article are those of the authors and do not necessarily represent the views of the U.S. Fish and Wildlife Service. This article is Contribution 0000 of the U.S. Geological Survey, Great Lakes Science Center. 


\section{References}

Abell, R., Allan, J.D., Lehner, B., 2007. Unlocking the potential of protected areas for freshwaters. Biological Conservation 134, 48-63.

Agardy, T., Bridgewater, P., Crosby, M.P., Day, J., Dayton, P.K., Kenchington, R., Laffoley, D., McConney, P., Murray, P.A., Parks, J.E., Peau, L., 2003. Dangerous targets? Unresolved issues and ideological clashes around marine protected areas. Aquatic Conservation-Marine and Freshwater Ecosystems 13, 353-367.

Agardy, T., Notarbartolo di Sciara, G., Christie, P., 2011. Mind the gap: Addressing the shortcomings of marine protected areas through large scale marine spatial planning. Marine Policy 35, 226-232.

Akins, A.L., Hansen, M.J., Seider, M.J., 2015. Effectiveness of a Refuge for Lake Trout in Western Lake Superior II: Simulation of Future Performance. North American Journal of Fisheries Management 35, 1003-1018.

Allison, G.W., Lubchenco, J., Carr, M.H., 1998. Marine Reserves are Necessary but Not Sufficient for Marine Conservation. Ecological Applications 8, S79-S92.

Babcock, E.A., MacCall, A.D., 2011. How useful is the ratio of fish density outside versus inside no-take marine reserves as a metric for fishery management control rules? Canadian Journal of Fisheries and Aquatic Sciences 68, 343-359.

Babcock, E.A., Pikitch, E.K., 2004. Can We Reach Agreement on a Standardized Approach to Ecosystem-based Fishery Management? Bulletin of Marine Science 74, 685-692.

Babcock, R.C., Shears, N.T., Alcala, A.C., Barrett, N.S., Edgar, G.J., Lafferty, K.D., McClanahan, T.R., Russ, G.R., 2010. Decadal trends in marine reserves reveal differential rates of change in direct and indirect effects. Proceedings of the National Academy of Sciences 107, 18256-18261.

Baskett, M.L., Micheli, F., Levin, S.A., 2007. Designing marine reserves for interacting species: Insights from theory. Biological Conservation 137, 163-179.

Bengtsson, J., Angelstam, P., Elmqvist, T., Emanuelsson, U., Folke, C., Ihse, M., Moberg, F., Nyström, M., 2003. Reserves, Resilience and Dynamic Landscapes. Ambio 32, 389-396.

Botsford, L., Brumbaugh, D., Grimes, C., Kellner, J., Largier, J., O’Farrell, M., Ralston, S., Soulanille, E., Wespestad, V., 2009. Connectivity, sustainability, and yield: bridging the gap between conventional fisheries management and marine protected areas. Reviews in Fish Biology and Fisheries 19, 69.

Bronte, C.R., Ebener, M.P., Schreiner, D.R., DeVault, D.S., Petzold, M.M., Jensen, D.A., Richards, C., Lozano, S.J., 2003. Fish community change in Lake Superior, 1970-2000. Canadian Journal of Fisheries \& Aquatic Sciences 60, 1552-1574.

Bronte, C.R., Schram, S.T., Selgeby, J.H., Swanson, B.L., 1995a. Density-Independent Survival of Wild Lake Trout in the Apostle Islands Area of Lake Superior. Journal of Great Lakes Research 21, 246-252.

Bronte, C.R., Schram, S.T., Selgeby, J.H., Swanson, B.L., 2002. Reestablishing a Spawning Population of Lake Trout in Lake Superior with Fertilized Eggs in Artificial Turf Incubators. North American Journal of Fisheries Management 22, 796-805. 
Bronte, C.R., Selgeby, J.H., Saylor, J.H., Miller, G.S., Foster, N.R., 1995b. Hatching, Dispersal, and Bathymetric Distribution of Age-0 Wild Lake Trout at the Gull Island Shoal Complex, Lake Superior. Journal of Great Lakes Research 21, Supplement 1, 233-245.

Coberly, C.E., Horrall, R.M., 1980. Fish spawning grounds in Wisconsin waters of the Great Lakes, Madison, WI.

Conner, D.J., Bronte, C.R., Selgeby, J.H., Collins, H.L., 1993. Food of Salmonine predators in Lake Superior, 1981-1987. Great Lakes Fishery Commission.

Corradin, L.M., Hansen, M.J., Schreiner, D.R., Seider, M.J., 2008. Recruitment Dynamics of Lake Trout in Western Lake Superior during 1988-1995. North American Journal of Fisheries Management 28, 663-677.

Dryer, W.R., 1964. Movements, growth, and rate of recapture of whitefish tagged in the Apostle Islands area of Lake Superior, Fishery Bulletin, pp. 611-618.

Dryer, W.R., Beil, J., 1964. Life history of lake herring in Lake Superior, U.S. Fish and Wildlife Service Fisheries Bulletin. U.S. Fish and Wildlife Service, pp. 493-530.

Ebener, M.P., 1997. Recovery of lake whitefish populations in the Great Lakes: a story of successful management and just plain luck. Fisheries 22, 18-20.

Ebener, M.P., Brenden, T.O., Wright, G.M., Jones, M.L., Faisal, M., 2010. Spatial and temporal distributions of lake whitefish spawning stocks in Northern lakes Michigan and Huron, 2003-2008. Journal of Great Lakes Research 36, Supplement 1, 38-51.

Ebener, M.P., Kinnunen, R.E., Schneeberger, P.J., Mohr, L.C., Hoyle, J.A., Peeters, P., 2008a. Management of lake whitefish commercial fisheries, in: Schechter, M.G., Leonard, N.J., Taylor, W.W. (Eds.), International governance of fisheries ecosystems: learning from the past, finding solutions for the future. American Fisheries Society, Bethesda, Md., pp. 99-143.

Ebener, M.P., Schreiner, D.R., 2007. Fisheries of Lake Superior, in: Ebener, M.P. (Ed.), The state of Lake Superior in 2000. Spec. Pub. 07-02, pp. 17-27.

Ebener, M.P., Stockwell, J.D., Yule, D.L., Gorman, O.T., Hrabik, T.R., Kinnunen, R.E., Mattes, W.P., Oyadomari, J.K., Schreiner, D.R., Geving, S., Scribner, K., Schram, S.T., Seider, M.J., Sitar, S.P., 2008b. Status of cisco (Coregonus artedi) in Lake Superior during 1970-2006 and management and research considerations, Lake Superior Technical Report 1. Lake Superior Technical Committee, Great Lakes Fishery Commission, Ann Arbor, MI.

Fabrizio, M.C., Dorazio, R.M., Schram, S.T., 2001. Dynamics of individual growth in a recovering population of lake trout (Salvelinus namaycush). Canadian Journal of Fisheries \& Aquatic Sciences 58, 262.

Fox, J., Weisberg, S., 2011. An R Companion to Applied Regression. Sage, Thousand Oaks, CA.

Gell, F.R., Roberts, C.M., 2003. Benefits beyond boundaries: the fishery effects of marine reserves. Trends in Ecology \& Evolution 18, 448-455.

Gorman, O.T., Evrard, L.M., Cholwek, G.A., Falck, J.M., Vinson, M.R., 2010. Status and Trends of Prey Fish Population in Lake Superior, 2009, in: Survey, U.S.G. (Ed.). United States Geological Survey, Presented to: Great Lakes Fishery Commission, Lake Superior Committee Meeting, Windsor, CA, 23 March 2010. 
Graham, N.A.J., Evans, R.D., Russ, G.R., 2003. The effects of marine reserve protection on the trophic relationships of reef fishes on the Great Barrier Reef. Environmental Conservation 30, 200-208.

Halpern, B.S., Lester, S.E., Kellner, J.B., 2010. Spillover from marine reserves and the replenishment of fished stocks. Environmental Conservation 36, 268-276.

Halpern, B.S., Warner, R.R., 2002. Marine reserves have rapid and lasting effects. Ecology Letters 5, 361-366.

Hansen, M.J., 1999. Lake Trout in the Great Lakes: Basinwide Stock Collapse and Binational Restoration. Michigan State University Press, East Lansing.

Hansen, M.J., Ebener, M.P., Schorfhaar, R.G., Schram, S.T., Schreiner, D.R., Selgeby, J.H., Taylor, W.W., 1996. Causes of Declining Survival of Lake Trout Stocked in U.S. Waters of Lake Superior in 1963-1986. Transactions of the American Fisheries Society 125, 831-843.

Hansen, M.J., Peck, J.W., Schorfhaar, R.G., Selgeby, J.H., Schreiner, D.R., Schram, S.T., Swanson, B.L., MacCallum, W.R., Burnham-Curtis, M.K., Curtis, G.L., Heinrich, J.W., Young, R.J., 1995. Lake Trout (Salvelinus namaycush) Populations in Lake Superior and Their Restoration in 1959-1993. Journal of Great Lakes Research 21, 152-175.

Hedges, K.J., Koops, M.A., Mandrak, N.E., Johannsson, O.E., 2010. Use of aquatic protected areas in the management of large lakes. Aquatic Ecosystem Health \& Management 13, 135-142.

Hedges, K.J., Mandrak, N.E., Koops, M.A., Johannsson, O.E., 2011. Great Lakes Aquatic Protected Areas, Non-Theme Area Research Report (White Paper) to the Great Lakes Fishery Commission, Ann Arbor, MI.

Hilborn, R., Stokes, K., Maguire, J.-J., Smith, T., Botsford, L.W., Mangel, M., Orensanz, J., Parma, A., Rice, J., Bell, J., Cochrane, K.L., Garcia, S., Hall, S.J., Kirkwood, G.P., Sainsbury, K., Stefansson, G., Walters, C., 2004. When can marine reserves improve fisheries management? Ocean \& Coastal Management 47, 197-205.

Holey, M.E., Rybicki, R.W., Eck, G.W., Brown Jr, E.H., Marsden, J.E., Lavis, D.S., Toneys, M.L., Trudeau, T.N., Horrall, R.M., 1995. Progress Toward Lake Trout Restoration in Lake Michigan. Journal of Great Lakes Research 21, 128-151.

Horns, W.H., Bronte, C.R., Busiahn, T.R., Ebener, M.P., Eshenroder, R.L., Gorenflo, T., Kmiecik, N., Mattes, W., Peck, J.W., Petzold, M., Schreiner, D.R., 2003. Fish-community objectives for Lake Superior, in: Commission, G.L.F. (Ed.). Great Lakes Fishery Commission, p. 78.

Hughes, T.P., Bellwood, D.R., Folke, C., Steneck, R.S., Wilson, J., 2005. New paradigms for supporting the resilience of marine ecosystems. Trends in Ecology \& Evolution 20, 380-386.

Johnson, M.J., Hansen, M.J., Seider, M.J., 2015. Effectiveness of a Refuge for Lake Trout in Western Lake Superior I: Empirical Analysis of Past Performance. North American Journal of Fisheries Management 35, 988-1002.

Kapuscinski, K.L., Hansen, M.J., Schram, S.T., 2005. Movements of Lake Trout in U.S. Waters of Lake Superior, 1973-2001. North American Journal of Fisheries Management 25, 696-708. 
Krueger, C.C., Ebener, M., 2004. Rehabilitation of lake trout in the Great Lakes: past lessons and future challenges, in: J.M. Gunn, R.J.S., and R.A. Ryder (Ed.), Boreal Shield watersheds. Lake trout ecosystems in a changing environment. Lewis Publishers, Boca Raton, Florida, pp. 37-56.

Krueger, C.C., Jones, M.L., Taylor, W.W., 1995. Restoration of Lake Trout in the Great Lakes: Challenges and Strategies for Future Management. Journal of Great Lakes Research 21, 547-558.

Krueger, C.C., Swanson, B.L., Selgeby, J.H., 1986. Evaluation of hatchery-reared lake trout for reestablishment of populations in the Apostle Islands region of Lake Superior, 1960-84, in: Stroud, R.H. (Ed.), Fish Culture in Fisheries Management. American Fisheries Society, Bethesda, MD, pp. 93-107.

Lawrie, A.H., Rahrer, J.F., 1973. Lake Superior: A case history of the lake and its fisheries, Technical Report. Great Lakes Fishery Commission, Ann Arbor, MI.

Le Quesne, W.J.F., Codling, E.A., 2009. Managing mobile species with MPAs: the effects of mobility, larval dispersal, and fishing mortality on closure size. ICES J. Mar. Sci. 66, 122-131.

Linton, B.C., Hansen, M.J., Schram, S.T., Sitar, S.P., 2007. Dynamics of a Recovering Lake Trout Population in Eastern Wisconsin Waters of Lake Superior, 1980-2001. North American Journal of Fisheries Management 27, 940-954.

Liu, J., Dietz, T., Carpenter, S.R., Alberti, M., Folke, C., Moran, E., Pell, A.N., Deadman, P., Kratz, T., Lubchenco, J., Ostrom, E., Ouyang, Z., Provencher, W., Redman, C.L., Schneider, S.H., Taylor, W.W., 2007. Complexity of Coupled Human and Natural Systems. Science 317, 1513-1516.

Lynch, A.J., Taylor, W.W., Smith, K.D., 2010. The influence of changing climate on the ecology and management of selected Laurentian Great Lakes fisheries. Journal of Fish Biology 77, 1764-1782.

Madenjian, C.P., DeSorcie, T.J., 1999. Status of Lake Trout Rehabilitation in the Northern Refuge of Lake Michigan. North American Journal of Fisheries Management 19, 658-669.

Madenjian, C.P., Ebener, M.P., Desorcie, T.J., 2008. Lake Trout Population Dynamics at Drummond Island Refuge in Lake Huron: Implications for Future Rehabilitation. North American Journal of Fisheries Management 28, 979-992.

MDNR, 2011. 2011 Michigan fishing guide. Michgian Department of Natural Resources. Available: http://www.michigan.gov/documents/dnr/FishingGuide_11-low-res_347106_7.pdf. (October 13, 2011).

Muir, A.M., Krueger, C.C., Hansen, M.J., 2012. Re-establishing lake trout in the Laurentian Great Lakes. The past, present, and future, in: Taylor, W.W., Ferreri, C.P. (Eds.), Great Lakes fishery policy and management: a binational perspective. Michigan State University Press, East Lansing, Michigan, pp. 533-588.

Myers, J.T., Jones, M.L., Stockwell, J.D., Yule, D.L., 2009. Reassessment of the Predatory Effects of Rainbow Smelt on Ciscoes in Lake Superior. Transactions of the American Fisheries Society $138,1352-1368$. 
NRC, 2001. Marine Protected Areas: Tools for Sustaining Ocean Ecosystems. National Academy Press, Washington, D.C.

Pelc, R.A., Warner, R.R., Gaines, S.D., Paris, C.B., 2010. Detecting larval export from marine reserves. Proceedings of the National Academy of Sciences 107, 18266-18271.

Peters, R.L., Darling, J.D.S., 1985. The Greenhouse Effect and Nature Reserves. BioScience $35,707-717$.

Pinnegar, J.K., Polunin, N.V.C., Francour, P., Badalamenti, F., Chemello, R., HarmelinVivien, M.-L., Hereu, B., Milazzo, M., Zabala, M., D'Anna, G., Pipitone, C., 2000. Trophic cascades in benthic marine ecosystems: lessons for fisheries and protected-area management. Environmental Conservation 27, 179-200.

Pollnac, R., Christie, P., Cinner, J.E., Dalton, T., Daw, T.M., Forrester, G.E., Graham, N.A.J., McClanahan, T.R., 2010. Marine reserves as linked social-ecological systems. Proceedings of the National Academy of Sciences 107, 18262-18265.

Pollock, K.H., Yoshizaki, J., Fabrizio, M.C., Schram, S.T., 2007. Factors Affecting Survival Rates of a Recovering Lake Trout Population Estimated by Mark-Recapture in Lake Superior, 1969-1996. Transactions of the American Fisheries Society 136, 185-194.

Pratt, T.C., Gorman, O.T., Mattes, W.P., Myers, J.T., Quinlan, H.R., Schreiner, D.R., Seider, M.J., Sitar, S.P., Yule, D.L., and Yurista, P.M., 2016. The state of Lake Superior in 2011 [online]. Available from: http://www.glfc.org/pubs/SpecialPubs/Sp16_01.pdf [accessed 21 April 2016].

Quinn, T.J., II, Deriso, R.B., 1999. Quantitative fish dynamics. Oxford University Press, New York, NY.

Ray, B.A., Hrabik, T.R., Ebener, M.P., Gorman, O.T., Schreiner, D.R., Schram, S.T., Sitar, S.P., Mattes, W.P., Bronte, C.R., 2007. Diet and Prey Selection by Lake Superior Lake Trout during Spring, 1986-2001. Journal of Great Lakes Research 33, 104-113.

Roberts, C.M., Hawkins, J.P., Gell, F.R., 2005. The role of marine reserves in achieving sustainable fisheries. Philosophical Transactions of the Royal Society B: Biological Sciences $360,123-132$.

Russ, G.R., Alcala, A.C., 1996. Do marine reserves export adult fish biomass? Evidence from Apo Island, central Philippines. Marine Ecology Progress Series 132, 1-9.

Salomon, A.K., Waller, N.P., McIlhagga, C., Yung, R.L., Walters, C., 2002. Modeling the trophic effects of marine protected area zoning policies: a case study. Aquatic Ecology 36, 8595.

Sánchez Lizaso, J.L., Goñi, R., Reñones, O., García Chartón, J.A., Galzin, R., Bayle, J., Sánchez-Jerez, P., Pérez Ruzafa, A., Ramos, A.A., 2000. Density dependence in marine protected populations: a review. Environmental Conservation 27, 144-158.

Schram, S.T., Selgeby, J.H., Bronte, C.R., Swanson, B.L., 1995. Population Recovery and Natural Recruitment of Lake Trout at Gull Island Shoal, Lake Superior, 1964-1992. Journal of Great Lakes Research 21, 225-232. 
Seider, M.J., Schram, S.T., 2011. Population dynamics of lake whitefish in the Apostle Islands region of Lake Superior, Fisheries Management Report No. 154. Wisconsin Department of Natural Resources, Madison, WI.

Selgeby, J.H., 1982. Decline of Lake Herring (Coregonus artedii) In Lake Superior: An Analysis of the Wisconsin Herring Fishery, 1936-78. Canadian Journal of Fisheries and Aquatic Sciences 39, 554-563.

Shipp, R.L., 2003. A Perspective on Marine Reserves as a Fishery Management Tool. Fisheries 28, 10-21.

Sitar, S.P., Chong, S.C., Ebener, M.P., Halpern, T.N., Mattes, W.P., Seider, M.J., Symbal, M.J., 2010. Nearshore fish community: Lake trout, in: Gorman, O.T., Ebener, M.P., Vinson, M.R. (Eds.), The state of Lake Superior in 2005. Great Lakes Fishery Commission. Spec. Pub. 10-01, pp. 49-57.

Smith, S.H., Buettner, H.J., Hile, R., 1961. Fishery statistical districts of the Great Lakes, Technical Report, pp. 0-24.

Soto, C.G., 2001. The potential impacts of global climate change on marine protected areas. Reviews in Fish Biology and Fisheries 11, 181-195.

Stanley, J.G., Eschenroder, R.L., Hartman, W.L., 1987. Sanctuaries for lake trout in the Great Lakes (Contribution 676 of the National Fisheries Center - Great Lakes, U.S. Fish and Wildlife Service, Ann Arbor, MI), Coastal Zone '87, Seattle, WA.

Stockwell, J.D., Ebener, M.P., Black, J.A., Gorman, O.T., Hrabik, T.R., Kinnunen, R.E., Mattes, W.P., Oyadomari, J.K., Schram, S.T., Schreiner, D.R., Seider, M.J., Sitar, S.P., Yule, D.L., 2009. A Synthesis of Cisco Recovery in Lake Superior: Implications for Native Fish Rehabilitation in the Laurentian Great Lakes. North American Journal of Fisheries Management $29,626-652$.

Stockwell, J.D., Yule, D.L., Gorman, O.T., Isaac, E.J., Moore, S.A., 2006. Evaluation of Bottom Trawls as Compared to Acoustics to Assess Adult Lake Herring (Coregonus artedi) Abundance in Lake Superior. Journal of Great Lakes Research 32, 280-292.

Suski, C., Cooke, S., 2007. Conservation of Aquatic Resources through the Use of Freshwater Protected Areas: Opportunities and Challenges. Biodiversity and Conservation 16, 2015-2029.

Swanson, B.L., 1982. Artificial Turf as a Substrate for Incubating Lake Trout Eggs on Reefs in Lake Superior. The Progressive Fish-Culturist 44, 109-111.

Swanson, B.L., Swedberg, D.V., 1980. Decline and Recovery of the Lake Superior Gull Island Reef Lake Trout (Salvelinus namaycush) Population and the Role of Sea Lamprey (Petromyzon marinus) Predation. Canadian Journal of Fisheries and Aquatic Sciences 37, 20742080.

Taylor, W.W., Smale, M.A., Freeberg, M.H., 1987. Biotic and Abiotic Determinants of Lake Whitefish (Coregonus ciupeaformis) Recruitment in Northeastern Lake Michigan. Canadian Journal of Fisheries and Aquatic Sciences 44, s313-s323.

Vandeperre, F., Higgins, R.M., Sánchez-Meca, J., Maynou, F., Goñi, R., Martín-Sosa, P., Pérez-Ruzafa, A., Afonso, P., Bertocci, I., Crec'hriou, R., D’Anna, G., Dimech, M., Dorta, C., 
Esparza, O., Falcón, J.M., Forcada, A., Guala, I., Le Direach, L., Marcos, C., Ojeda-Martínez, C., Pipitone, C., Schembri, P.J., Stelzenmüller, V., Stobart, B., Santos, R.S., 2010. Effects of notake area size and age of marine protected areas on fisheries yields: a meta-analytical approach. Fish and Fisheries 12, 412-426.

WDNR, 2011. Guide to Wisconsin hook and line fishing regulations, 2011-2012. Wisconsin Department of Natural Resources, Bureau of Fisheries Management. Available: http://dnr.wi.gov/fish/regulations/2011/documents/FishingRegs11-12.pdf. (October 13, 2011).

Willis, T.J., Millar, R.B., Babcock, R.C., 2003. Protection of exploited fish in temperate regions: high density and biomass of snapper Pagrus auratus (Sparidae) in northern New Zealand marine reserves. Journal of Applied Ecology 40, 214-227.

Wisconsin State-Tribal Technical Committee, 2009. Recommended maximum lake trout harvest for the Apostle Islands region of Lake Superior for the 2010-2012 fishing years.

Yamamura, K., 1999. Transformation using $(x+0.5)$ to stabilize the variance of populations. Researches on Population Ecology 41, 229-234.

Yule, D.L., Stockwell, J.D., Cholwek, G.A., Evrard, L.M., Schram, S., Seider, M., Symbal, M., 2006. Evaluation of Methods to Estimate Lake Herring Spawner Abundance in Lake Superior. Transactions of the American Fisheries Society 135, 680-694.

Yule, D.L., Stockwell, J.D., Gorman, O.T., Pratt, T.C., 2010. Nearshore fish community: Prey fishes, in: Gorman, O.T., Ebener, M.P., Vinson, M.R. (Eds.), The state of Lake Superior in 2005. Great Lakes Fishery Commission. Spec. Pub. 10-01. 


\section{Tables}

TABLE 1.-Lake trout (Salvelinus namaycush), lake whitefish (Coregonus clupeaformis), and cisco (Coregonus artedi) linear model terms and associated ANCOVA parameter estimates for log-transformed CPUE of each species as a function of time and refuge status as described in equation 3. Fish were sampled at stations located inside versus outside of refuges in western Lake Superior during summer graded-mesh gill-net surveys during even years from 1982-2010.

\begin{tabular}{|c|c|c|c|c|}
\hline Model Type & Model Term & Estimate & Standard error & P-value \\
\hline \multirow[t]{4}{*}{ Lake trout (all) } & (Intercept) & 3.627 & 9.588 & 0.7054 \\
\hline & Year & $-8.973 \mathrm{E}-04$ & 4.807E-03 & 0.8520 \\
\hline & Refuge status & -50.970 & 20.270 & 0.0121 \\
\hline & Year $\times$ Refuge status & 0.026 & 0.010 & 0.0107 \\
\hline \multirow[t]{4}{*}{ Wild lake trout } & (Intercept) & -83.896 & 10.004 & $2.83 \mathrm{E}-16$ \\
\hline & Year & 0.043 & 0.005 & $<2 \mathrm{E}-16$ \\
\hline & Refuge status & -54.946 & 21.147 & 0.0096 \\
\hline & Year $\times$ Refuge status & 0.028 & 0.011 & 0.0082 \\
\hline \multirow[t]{4}{*}{ Stocked lake trout } & (Intercept) & 126.353 & 9.686 & $<2 \mathrm{E}-16$ \\
\hline & Year & -0.063 & 0.005 & $<2 \mathrm{E}-16$ \\
\hline & Refuge status & 27.154 & 20.475 & 0.185 \\
\hline & Year $\times$ Refuge status & -0.013 & 0.010 & 0.189 \\
\hline \multirow{3}{*}{$\begin{array}{l}\text { Stocked lake trout } \\
\text { (with interaction term } \\
\text { dropped from model) }\end{array}$} & (Intercept) & 132.379 & 8.538 & $<2 \mathrm{E}-16$ \\
\hline & Year & -0.066 & 0.004 & $<2 \mathrm{E}-16$ \\
\hline & Refuge status & 0.229 & 0.091 & 0.012 \\
\hline \multirow[t]{4}{*}{ Lake whitefish } & (Intercept) & -136.100 & 13.750 & $<2 \mathrm{E}-16$ \\
\hline & Year & 0.070 & 0.007 & $<2 \mathrm{E}-16$ \\
\hline & Refuge status & -124.800 & 29.070 & 2.01E-05 \\
\hline & Year $\times$ Refuge status & 0.062 & 0.015 & $2.52 \mathrm{E}-05$ \\
\hline \multirow[t]{4}{*}{ Cisco } & (Intercept) & -17.701 & 18.537 & 0.340 \\
\hline & Year & 0.010 & 0.009 & 0.264 \\
\hline & Refuge status & -12.216 & 39.185 & 0.755 \\
\hline & Year $\times$ Refuge status & 0.006 & 0.0196 & 0.771 \\
\hline
\end{tabular}

\section{Figure Captions}

FIGURE 1. Lake trout refuges in the Apostle Islands region of Wisconsin. (Inset: Lake Superior). Full refuge extent is indicated by the purple line surrounding cross-hatching. 
Detailed information about base layer data sources is available in Electronic Supplementary Material (ESM) Appendix S1. For interpretation of the references to color in this and all other figures, the reader is referred to the electronic version of this paper.

FIGURE 2. Lake trout refuges, seasonal fishing areas, and summer graded-mesh survey stations in the Apostle Islands, Lake Superior. Stations missing coordinates but identified by the WDNR as being located inside or outside of the refuges are indicated by orange triangles and are not representative of exact locations. Detailed information about base layer data sources and map development of refuge zones is available in ESM Appendix S1.

FIGURE 3. Annual mean CPUE of wild and stocked lake trout (Salvelinus namaycush) against time, inside vs. outside of the refuges in western Lake Superior. Lake trout stocking ceased in 1994. Error bars are $+/$ - one standard deviation (SD) from the annual means.

FIGURE 4. Annual log-transformed mean wild (a) and stocked (b) lake trout (Salvelinus namaycush) CPUE in the Apostle Islands region of Lake Superior, 1982-2010. Predicted values (with 95\% confidence intervals) from fitted linear model.

FIGURE 5. Annual mean lake whitefish (Coregonus clupeaformis) CPUE (+/- SD) in the Apostle Islands region of Lake Superior during even years, 1970-2010. The red dotted vertical lines correspond to establishment of the Gull Island Shoal Refuge (1976) and the Devils Island Shoal Refuge (1981). Data were not available for 1996.

FIGURE 6. Annual log-transformed mean lake whitefish (Coregonus clupeaformis) CPUE in the Apostle Islands region of Lake Superior, 1982-2010. Predicted values (with 95\% confidence intervals) from fitted linear model.

FIGURE 7. Annual mean cisco (Coregonus artedi) CPUE (+/- SD) in the Apostle Islands region of Lake Superior during even years, 1970-2010. The red dotted vertical lines correspond to establishment of the Gull Island Shoal Refuge (1976) and the Devils Island Shoal Refuge (1981). Data were not available for 1996. 
Figure 1 (color)

Lake trout refuges (full extent)

Mainland and Apostle Islands' shorelines

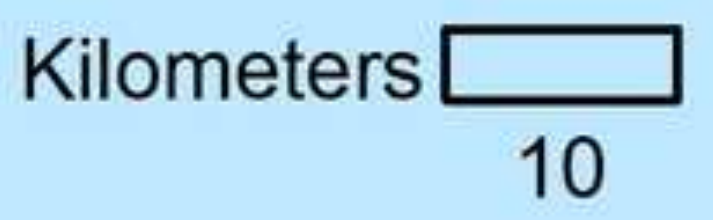

Devils Island Shoal

\section{Refuge}
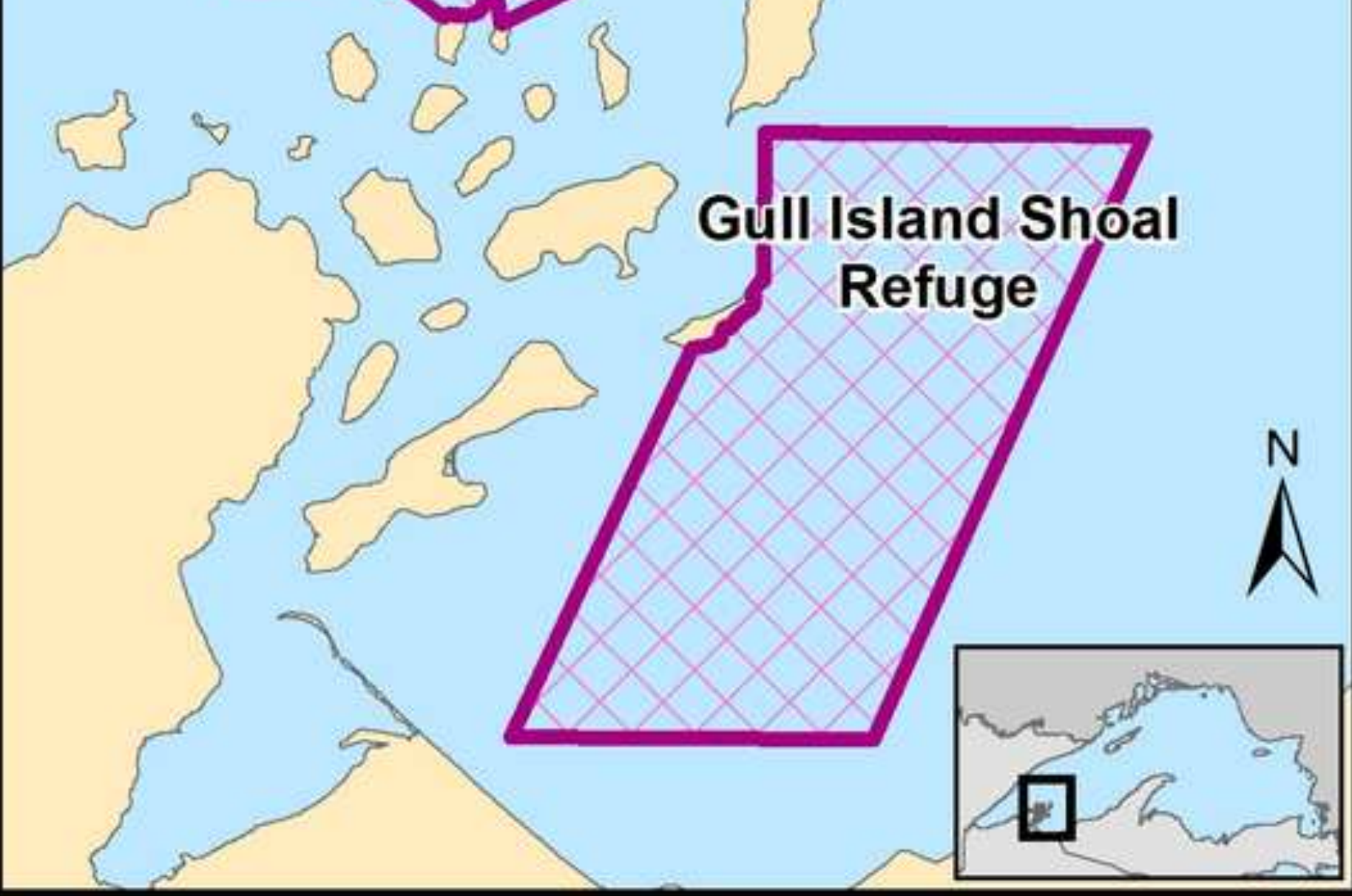


\section{Lake trout refuges (full extent)}

Mainland and Apostle Islands' shorelines

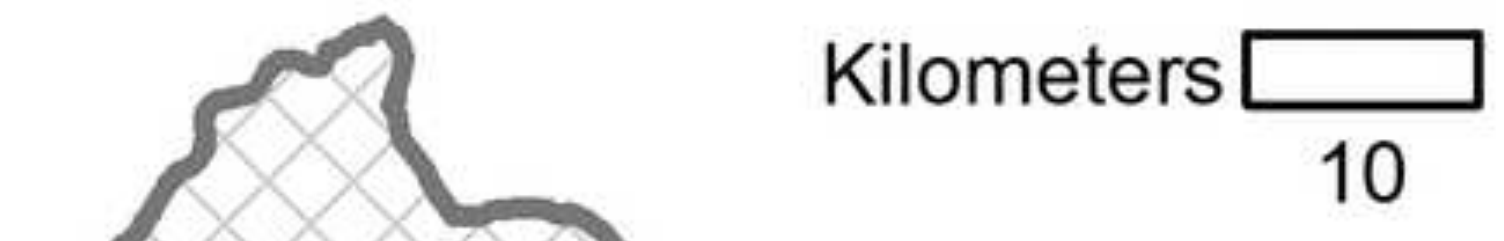

Devils Island Shoal

\section{Refuge}

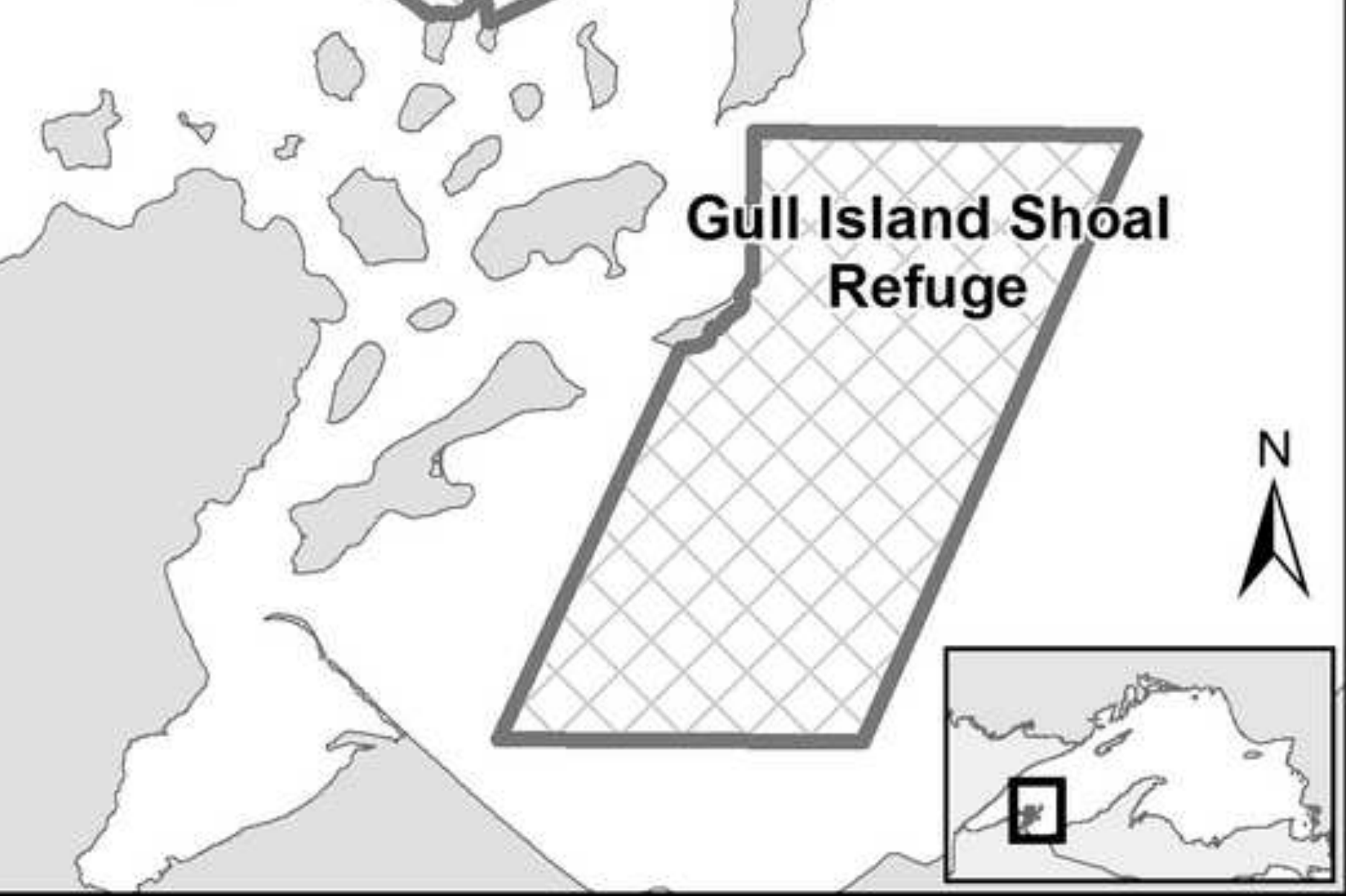




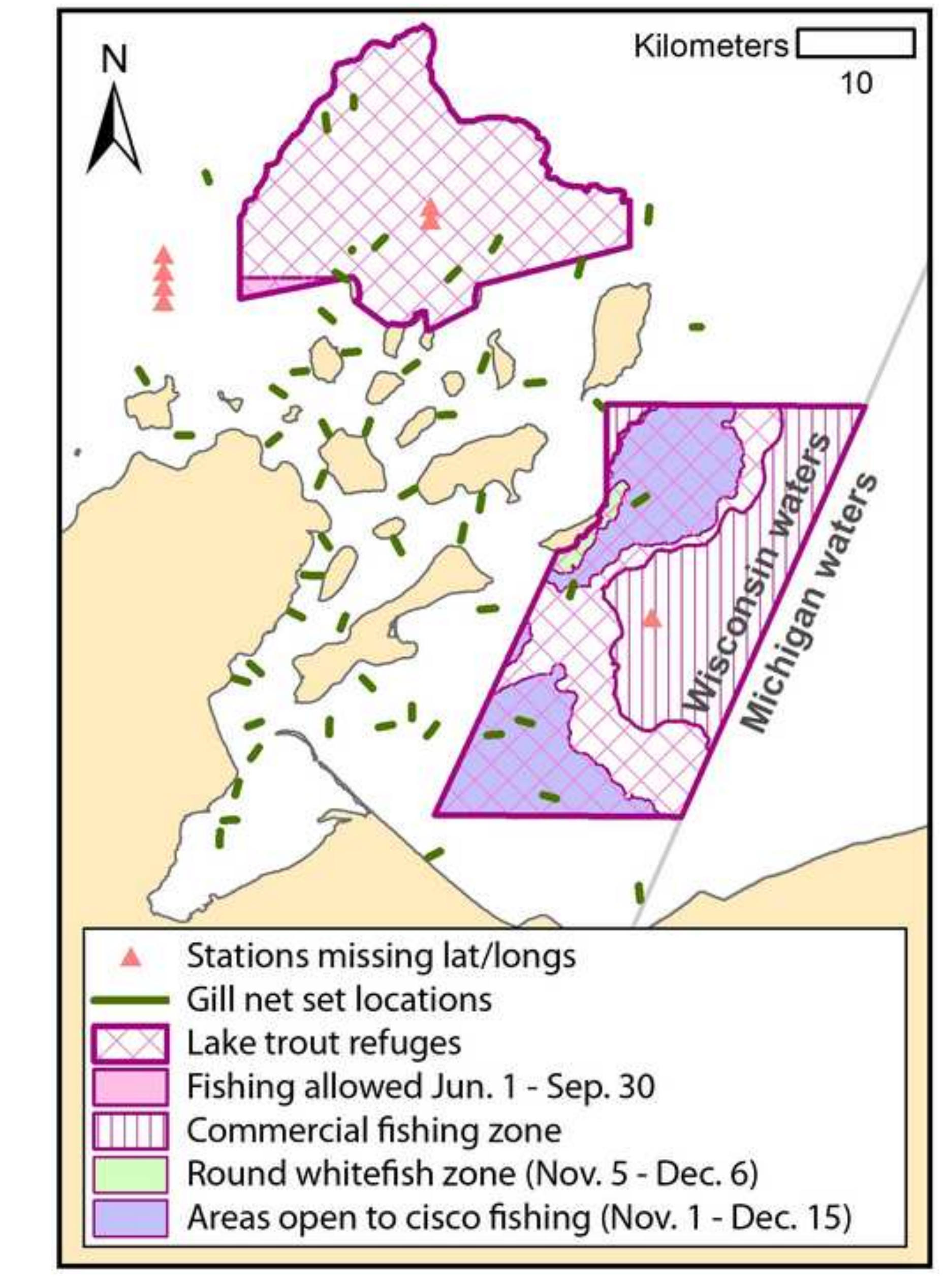

Figure 2 (color)

\section{Figure 2 (color)}




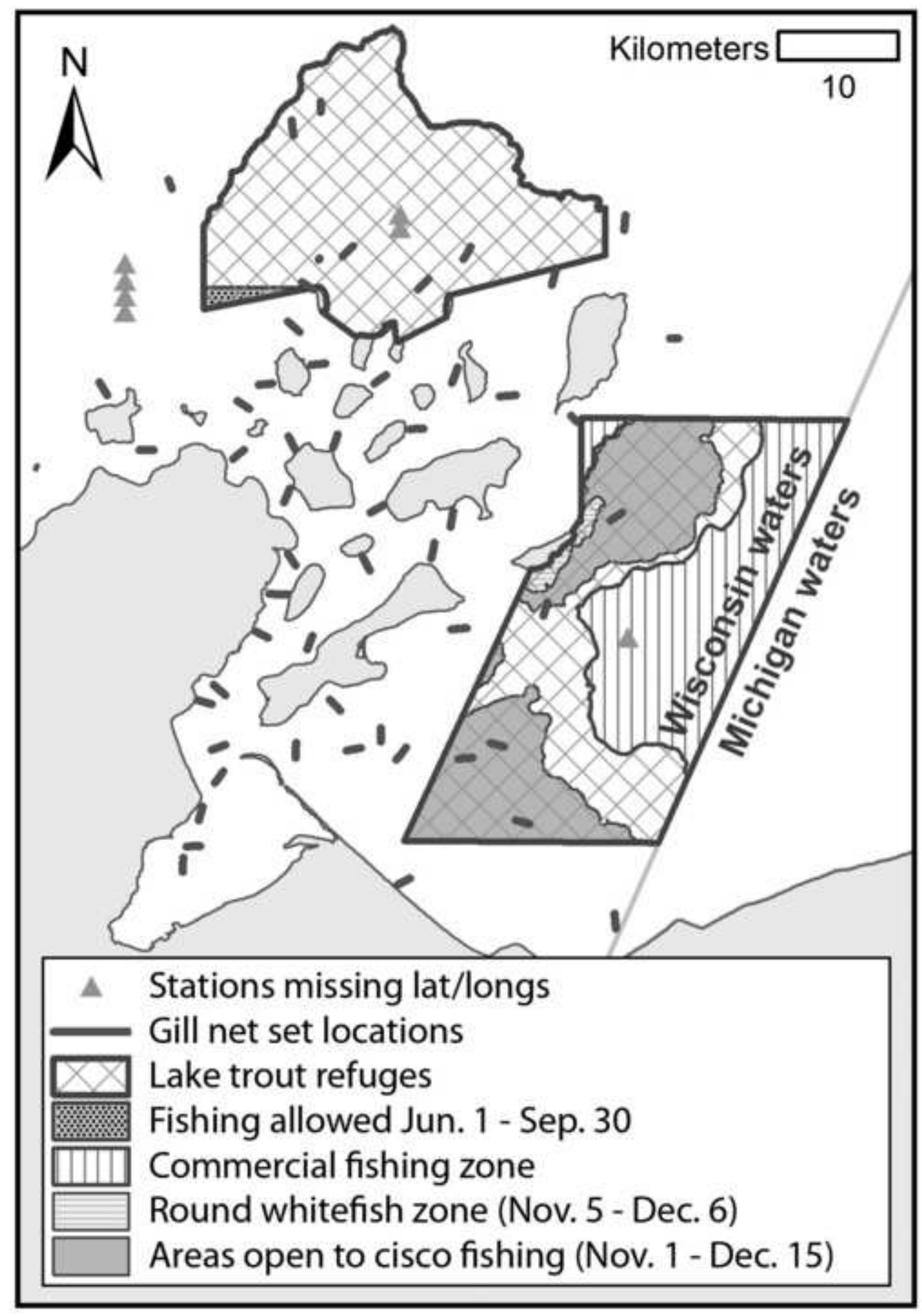

Figure 2 (grayscale) 


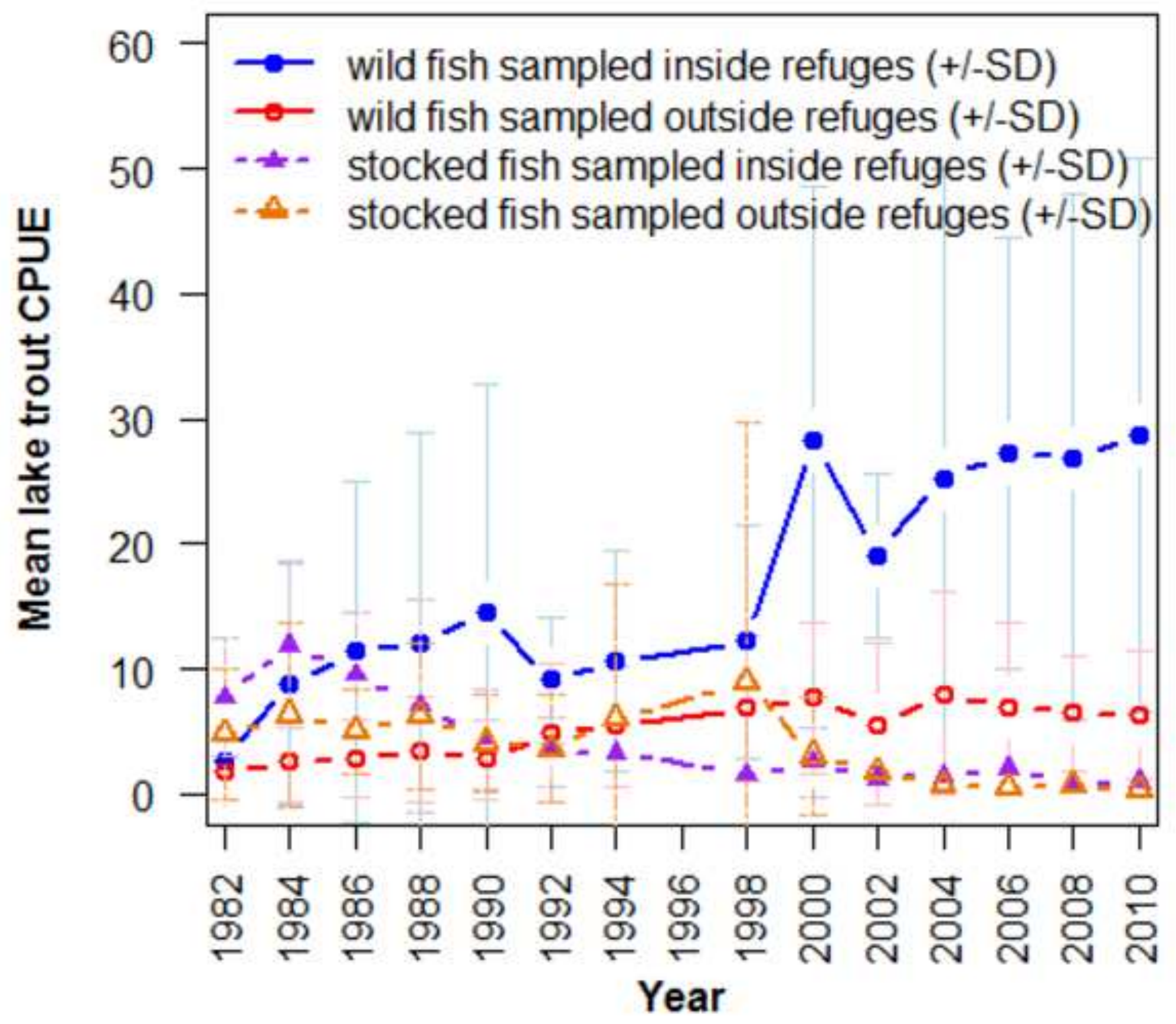




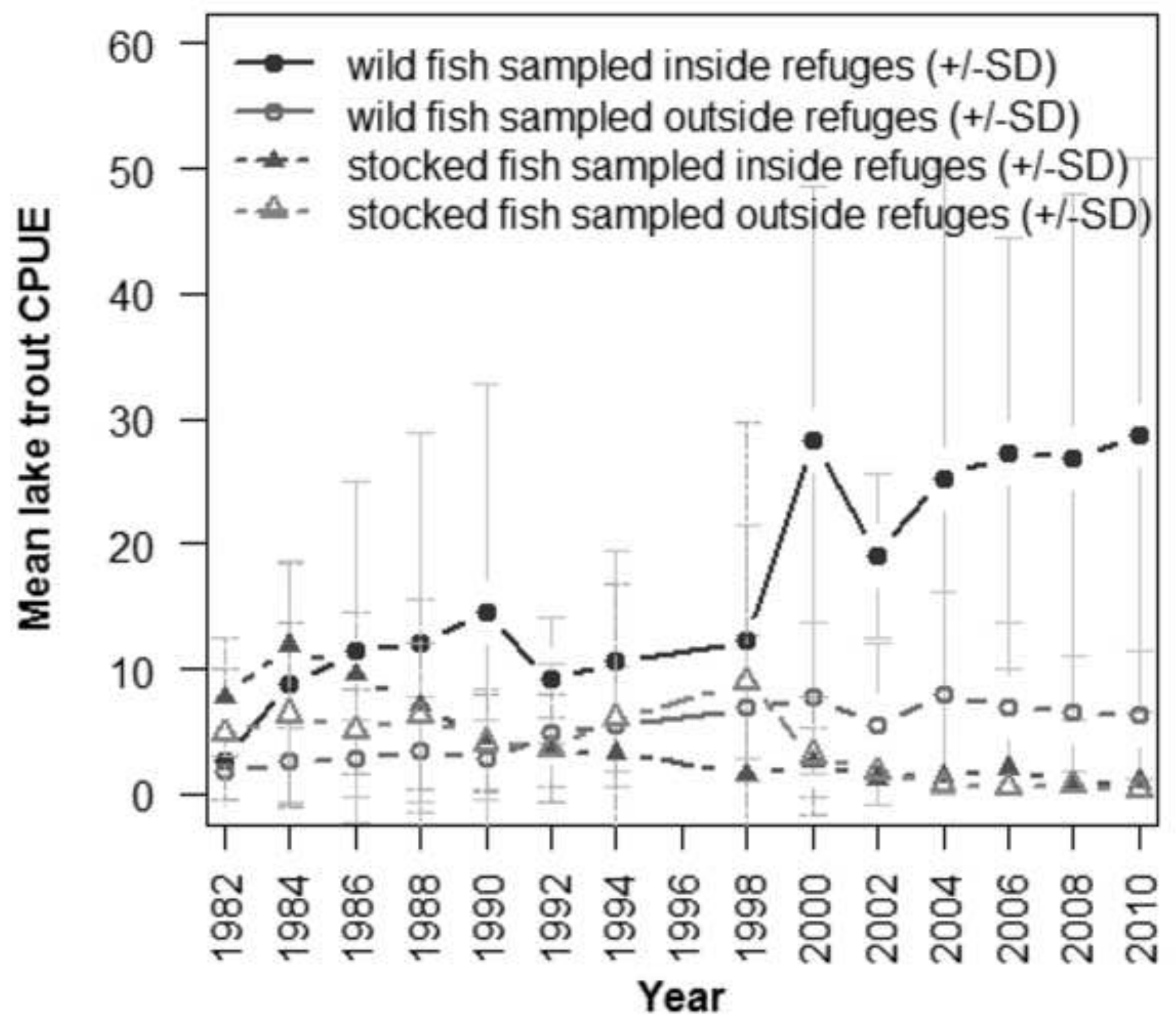


(a) Wild fish

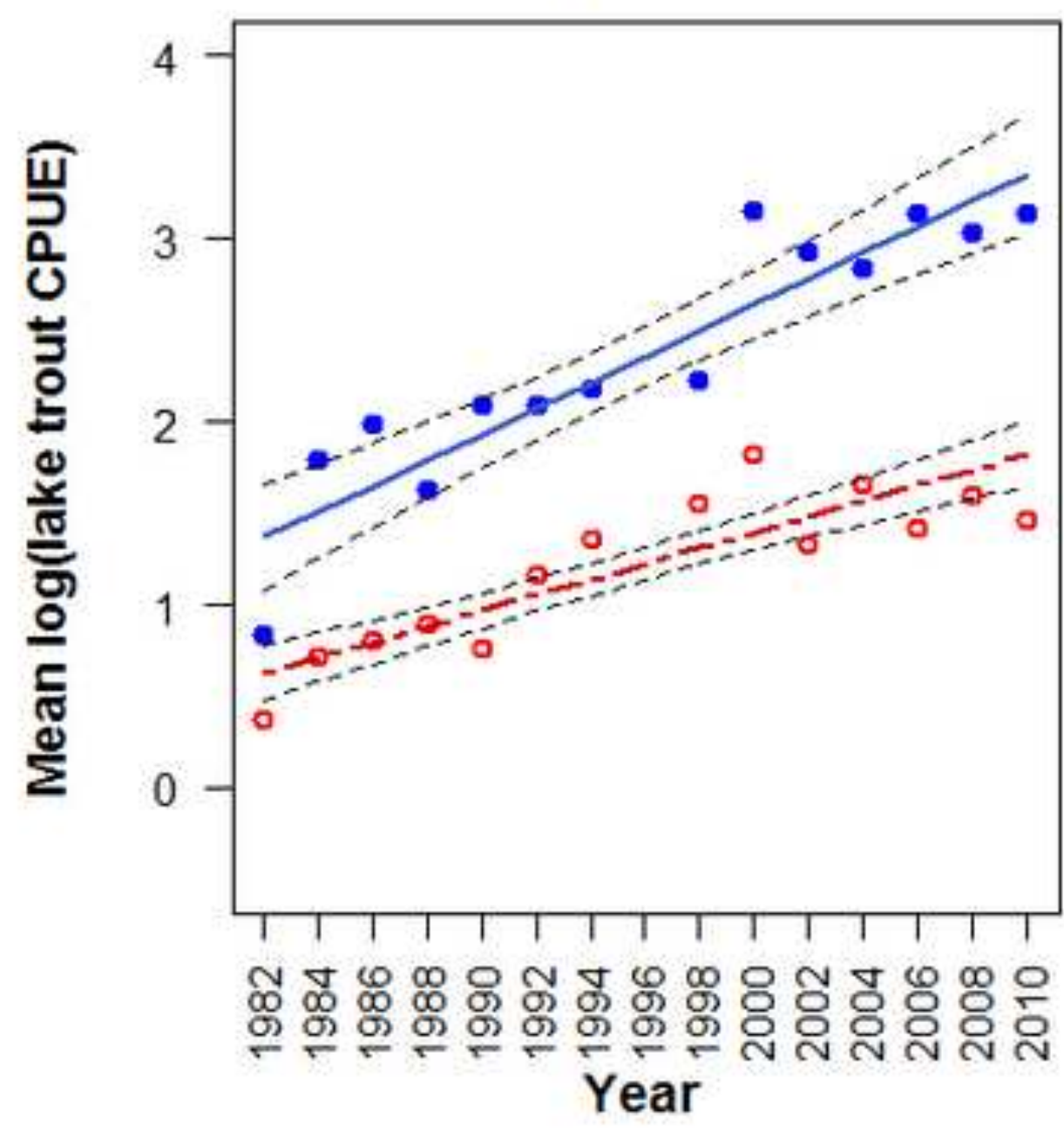

(b) Stocked fish

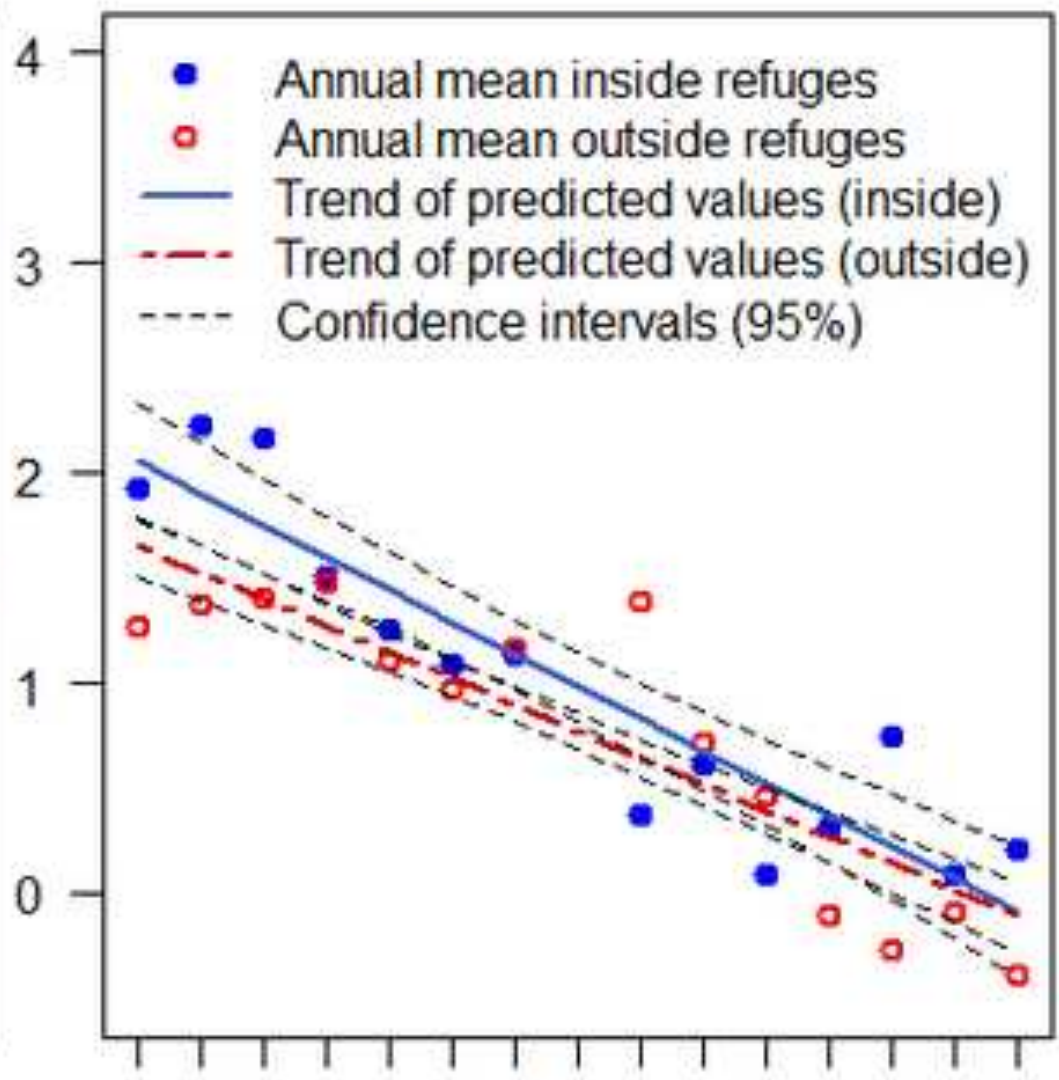

퐁 ळ\% Year 
(a) Wild fish

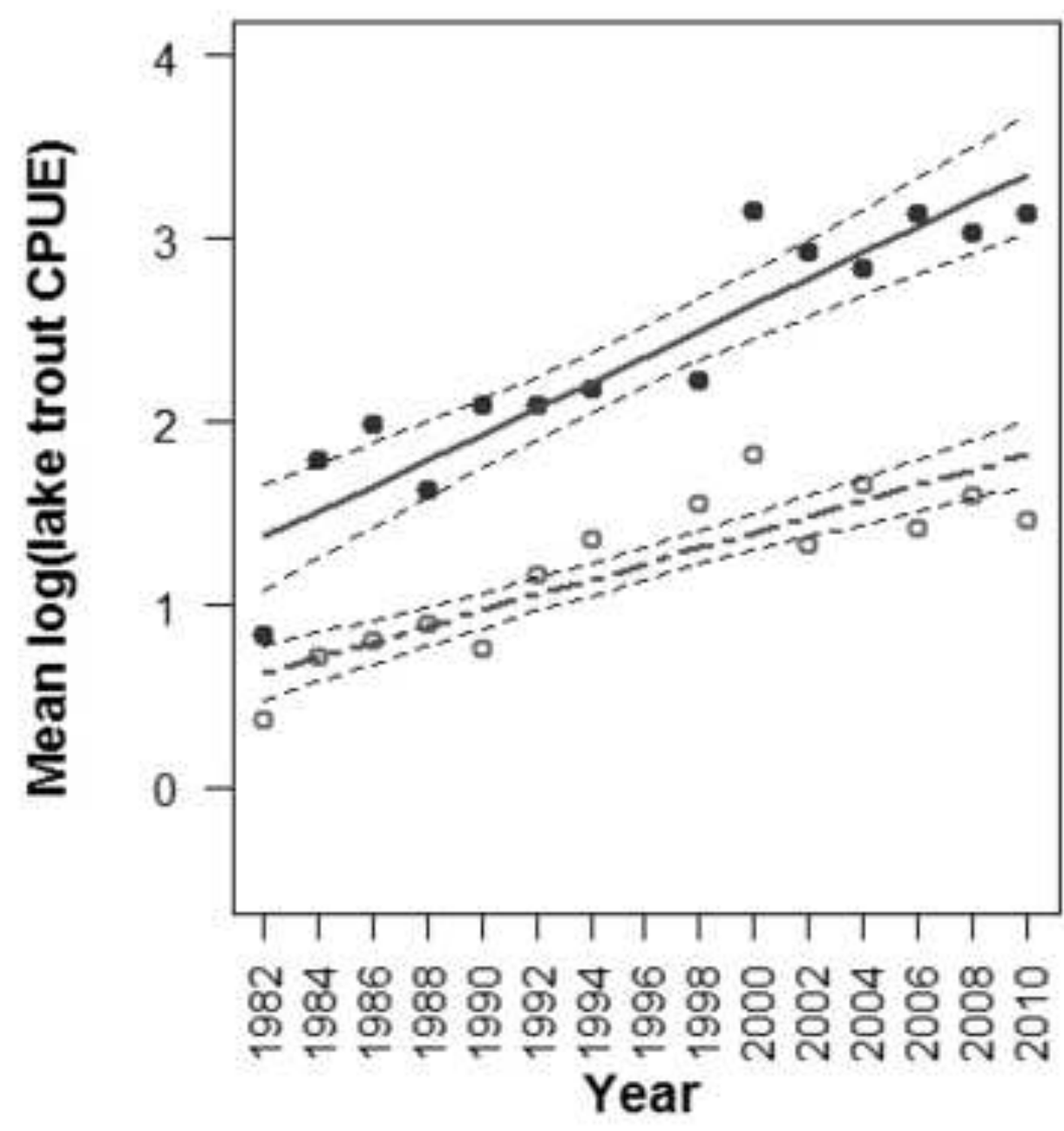

(b) Stocked fish

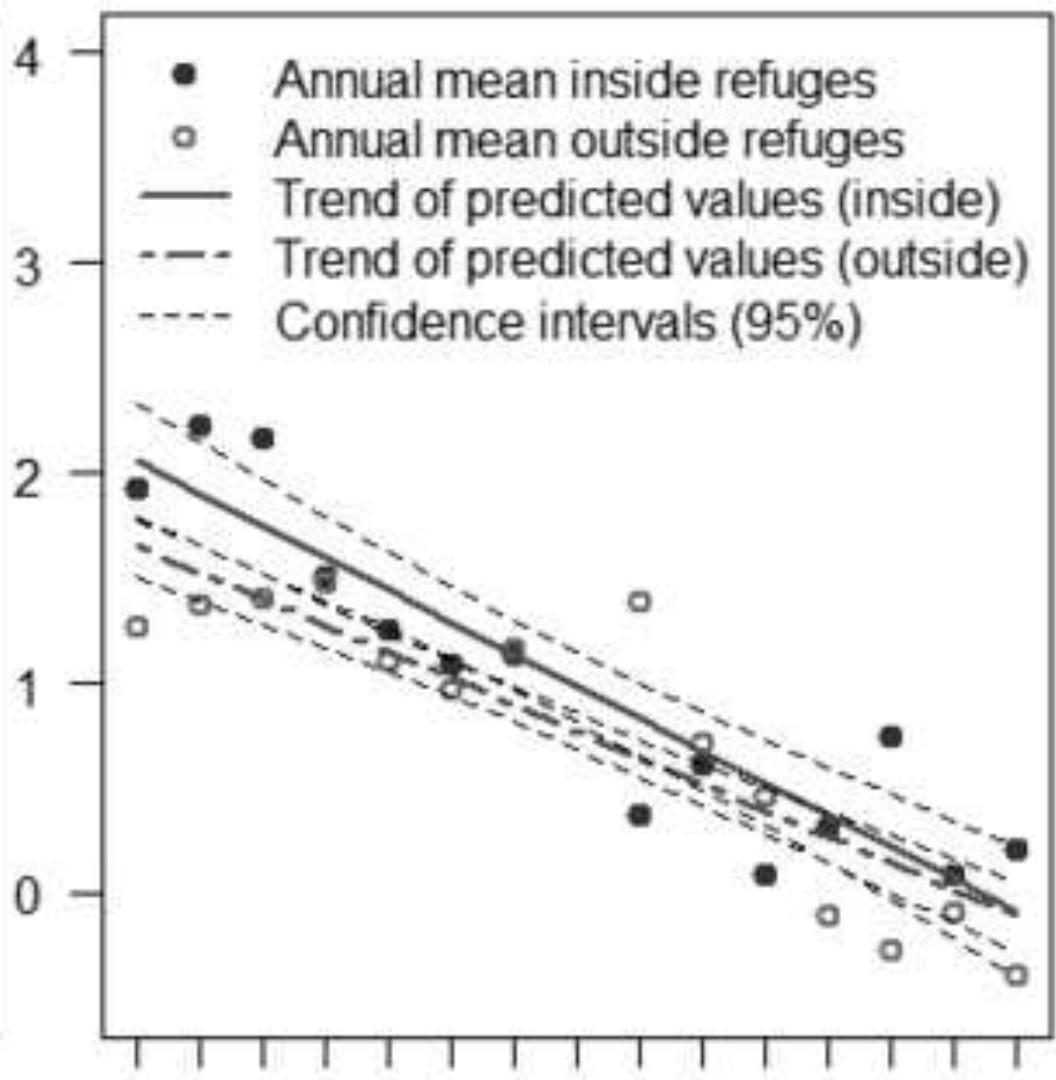

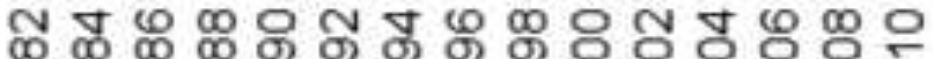
\% Year 


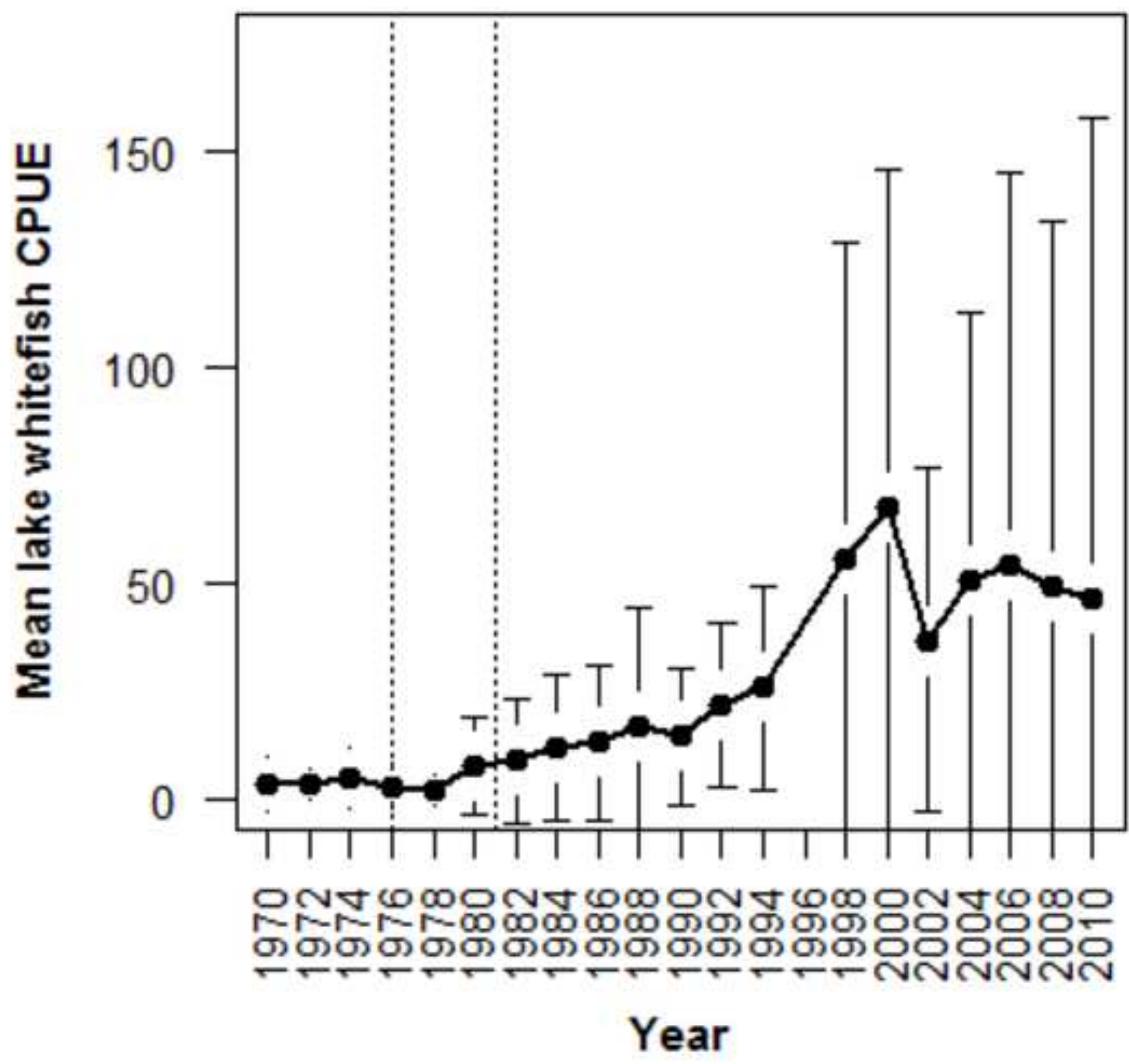




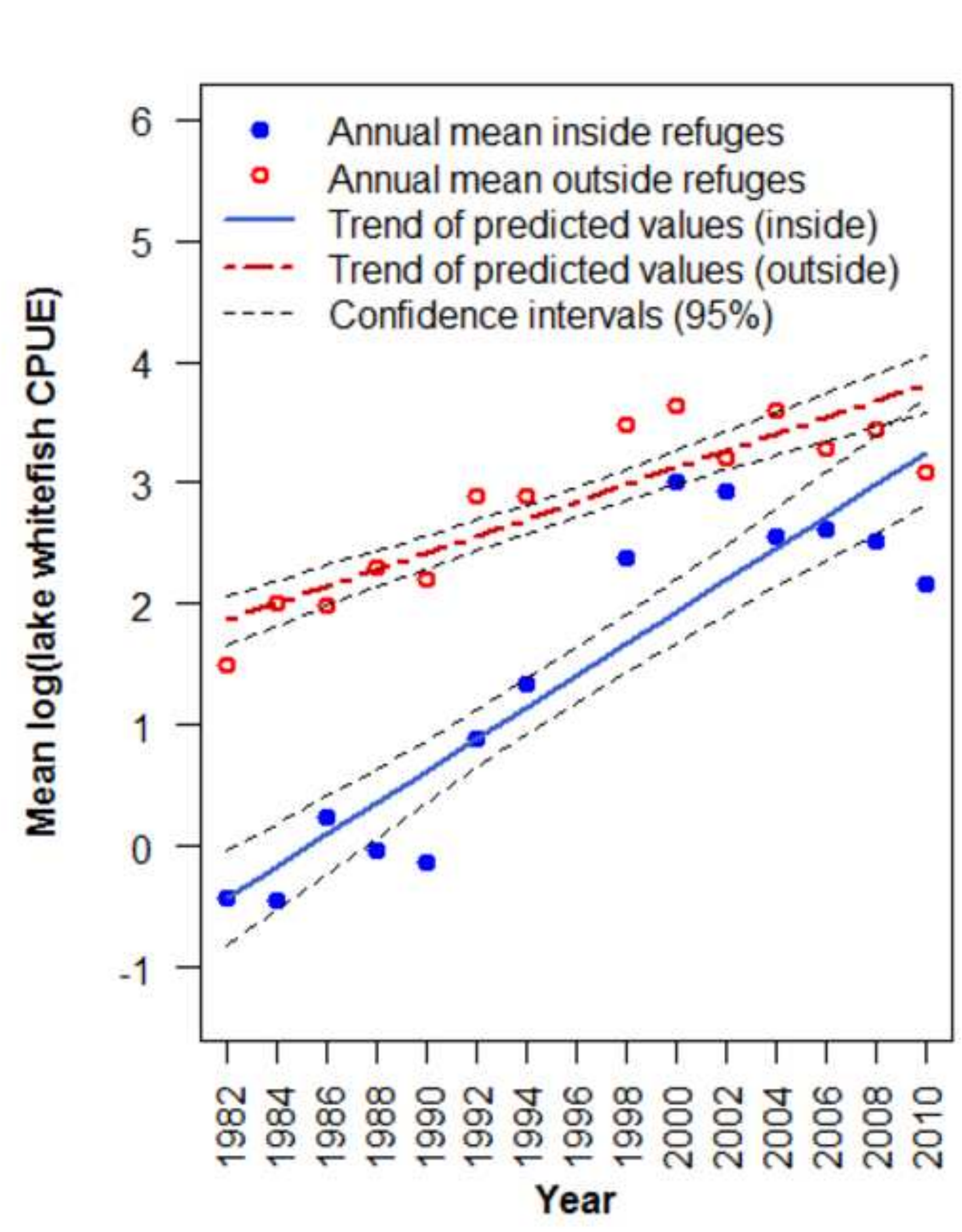

Figure 6 (color)

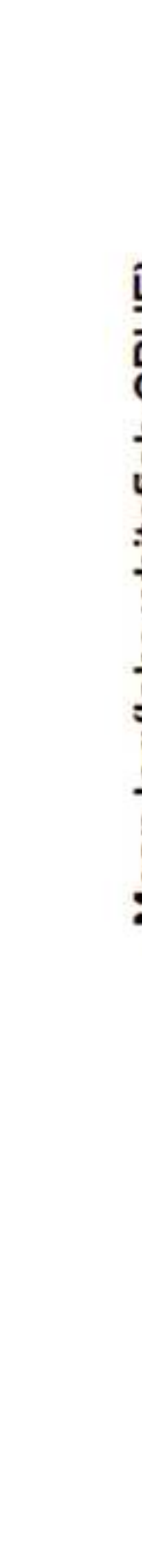

.




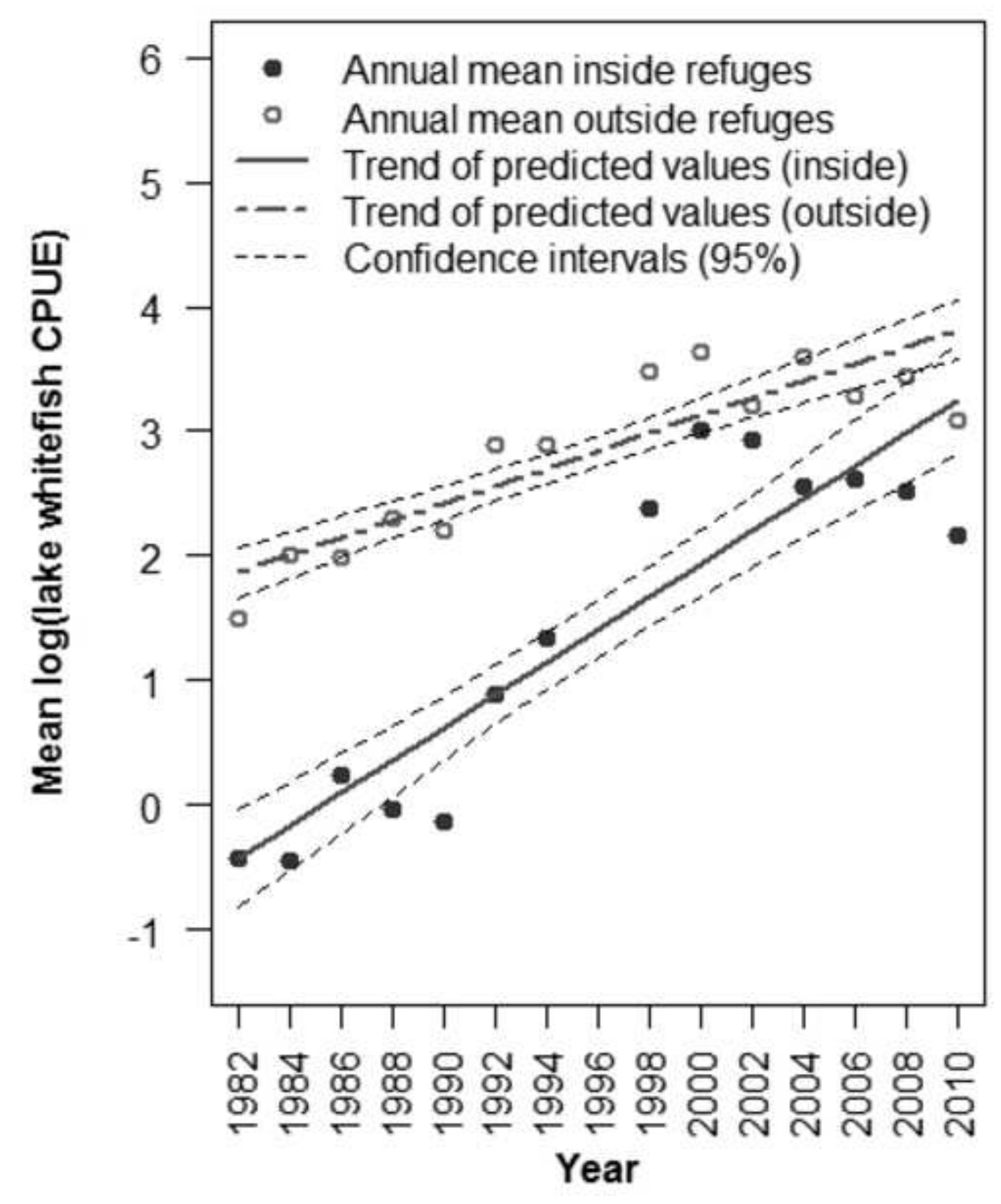

Figure 6 (grayscale)

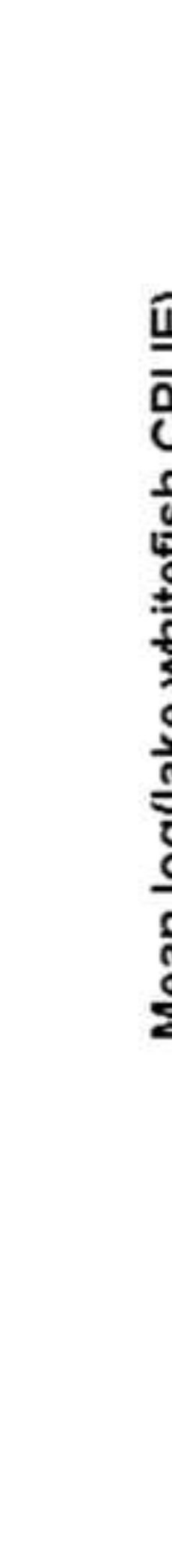

(1)

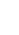

$-2$

$-$
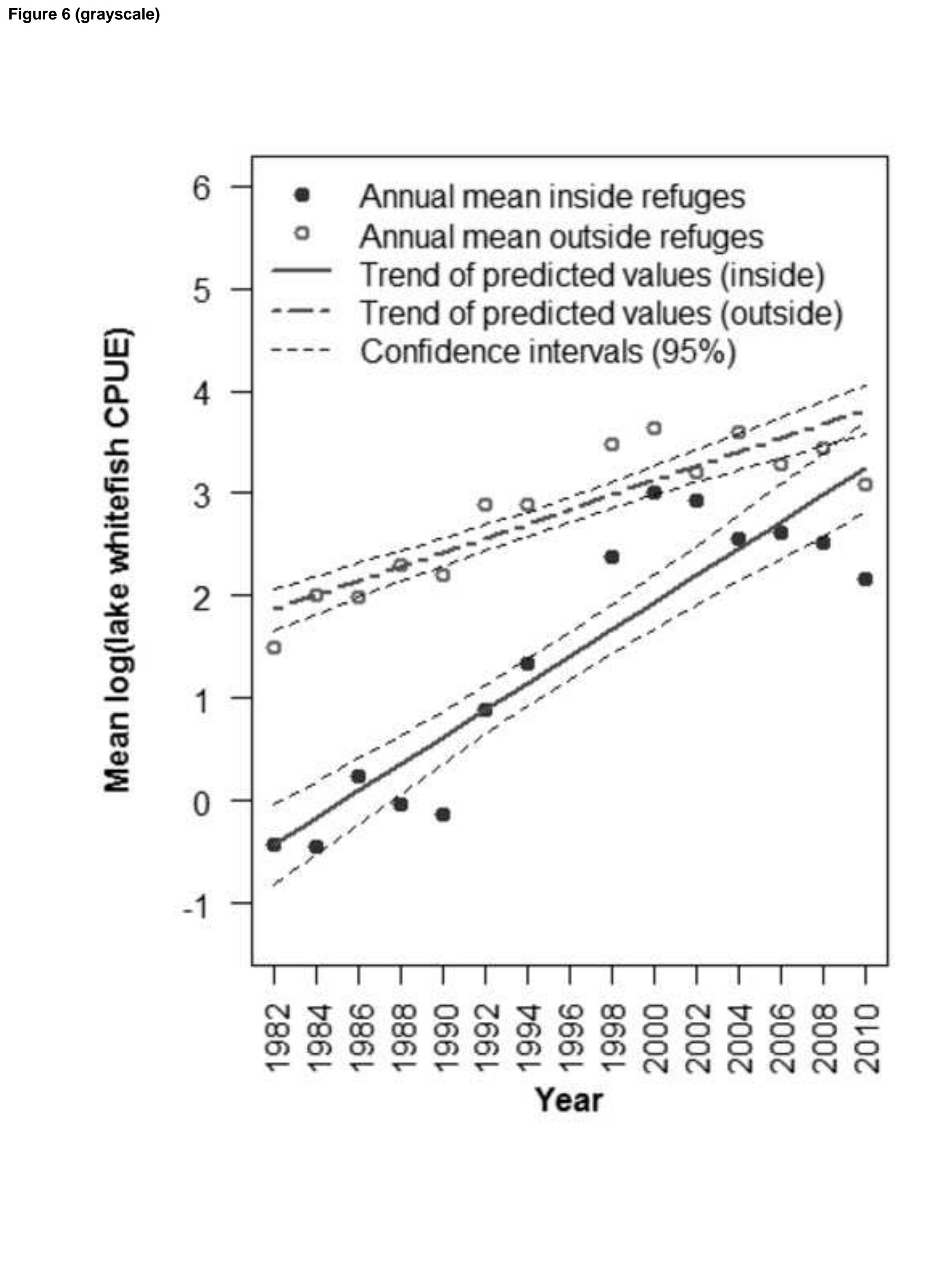

$1+1$ 


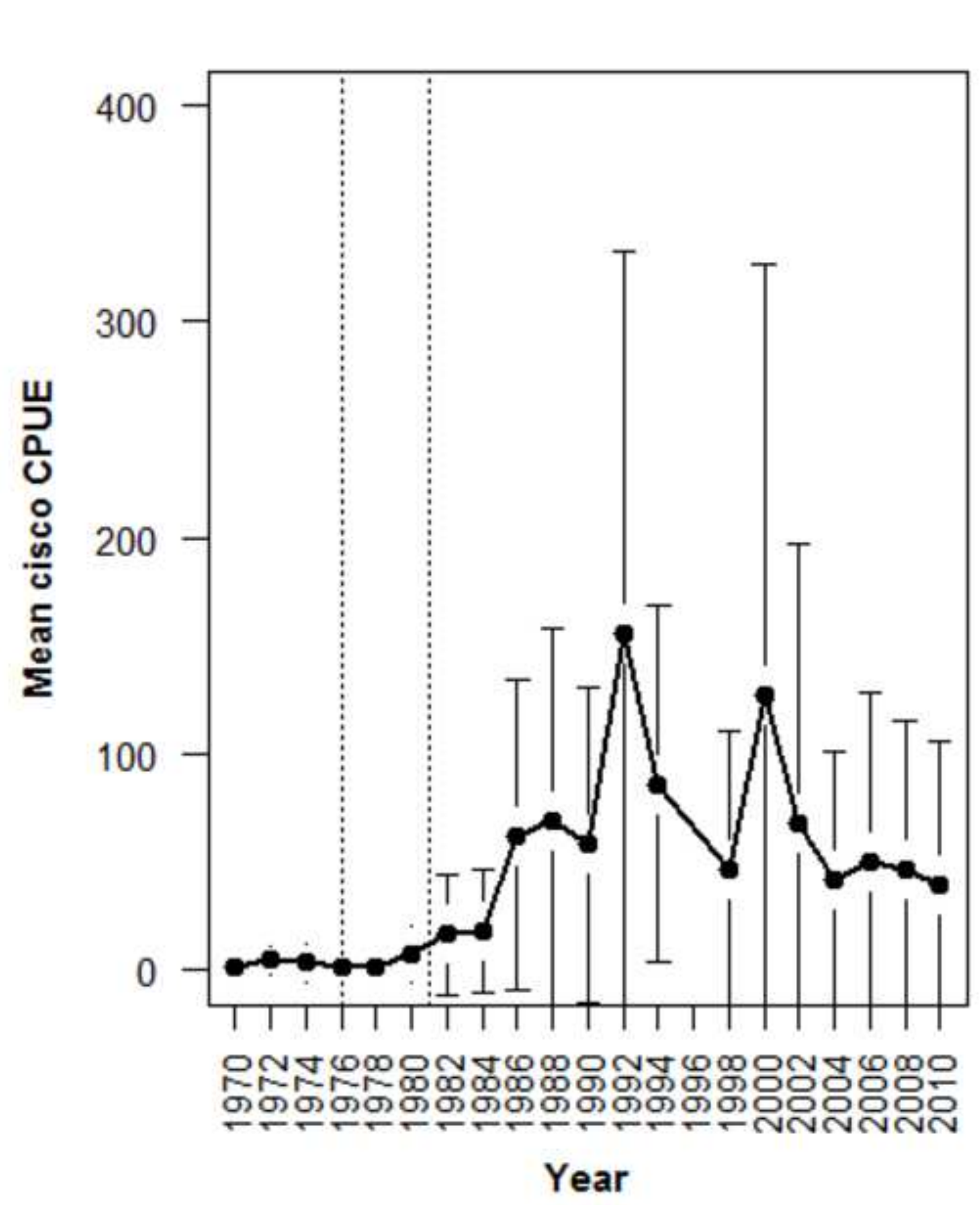

Figure 7

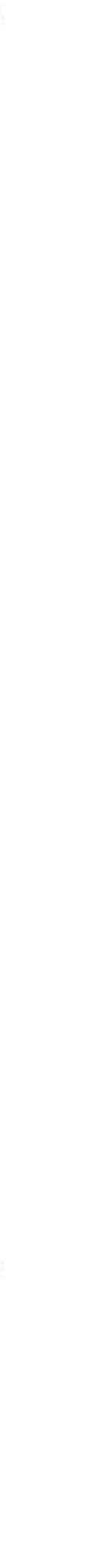

